\title{
The formaldehyde budget as seen by a global-scale multi-constraint and multi-species inversion system
}

\author{
A. Fortems-Cheiney ${ }^{1}$, F. Chevallier ${ }^{1}$, I. Pison ${ }^{1}$, P. Bousquet ${ }^{1}$, M. Saunois ${ }^{1}$, S. Szopa ${ }^{1}$, C. Cressot ${ }^{1}$, T. P. Kurosu ${ }^{2}$, \\ K. Chance ${ }^{3}$, and A. Fried ${ }^{4}$ \\ ${ }^{1}$ Laboratoire des Sciences du Climat et de 1'Environnement, CEA-CNRS-UVSQ, UMR8212, Gif-sur-Yvette, France \\ ${ }^{2}$ Jet Propulsion Laboratory, California Institute of Technology, USA \\ ${ }^{3}$ Atomic and Molecular Physics Division, Harvard-Smithsonian Center for Astrophysics, Cambridge, Massachusetts, USA \\ ${ }^{4}$ Earth Observing Laboratory, National Center for Atmospheric Research, Boulder, Colorado, USA
}

Correspondence to: A. Fortems-Cheiney (audrey.fortems@1sce.ipsl.fr)

Received: 16 February 2012 - Published in Atmos. Chem. Phys. Discuss.: 7 March 2012

Revised: 4 July 2012 - Accepted: 5 July 2012 - Published: 1 August 2012

\begin{abstract}
For the first time, carbon monoxide (CO) and formaldehyde (HCHO) satellite retrievals are used together with methane $\left(\mathrm{CH}_{4}\right)$ and methyl choloroform $\left(\mathrm{CH}_{3} \mathrm{CCl}_{3}\right.$ or $\mathrm{MCF})$ surface measurements in an advanced inversion system. The $\mathrm{CO}$ and $\mathrm{HCHO}$ are respectively from the MOPITT and OMI instruments. The multi-species and multisatellite dataset inversion is done for the 2005-2010 period. The robustness of our results is evaluated by comparing our posterior-modeled concentrations with several sets of independent measurements of atmospheric mixing ratios. The inversion leads to significant changes from the prior to the posterior, in terms of magnitude and seasonality of the $\mathrm{CO}$ and $\mathrm{CH}_{4}$ surface fluxes and of the $\mathrm{HCHO}$ production by nonmethane volatile organic compounds (NMVOC). The latter is significantly decreased, indicating an overestimation of the biogenic NMVOC emissions, such as isoprene, in the GEIA inventory. $\mathrm{CO}$ and $\mathrm{CH}_{4}$ surface emissions are increased by the inversion, from 1037 to $1394 \mathrm{TgCO}$ and from 489 to $529 \mathrm{TgCH}_{4}$ on average for the 2005-2010 period. $\mathrm{CH}_{4}$ emissions present significant interannual variability and a joint $\mathrm{CO}-\mathrm{CH}_{4}$ fluxes analysis reveals that tropical biomass burning probably played a role in the recent increase of atmospheric methane.
\end{abstract}

\section{Introduction}

Formaldehyde ( $\mathrm{HCHO}$ ), found throughout the troposphere, is a short-lived tropospheric gas acting as an outdoor and indoor air pollutant, with a typical lifetime of a few hours in daytime (Sander et al., 2006). HCHO is produced in the background troposphere mainly through the chemical oxidation of methane $\left(\mathrm{CH}_{4}\right)$ by hydroxyl radicals $(\mathrm{OH})$. In the continental boundary layer, the HCHO source from the oxidation of non-methane volatile organic compounds NMVOC (i.e. alkanes, alkenes, aromatic hydrocarbons and isoprene) dominates over the methane oxidation source and can make a large contribution to tropospheric $\mathrm{HCHO}$ concentrations. $\mathrm{HCHO}$ is emitted into the atmosphere by fuel combustion processes, biomass burning (Lee et al., 1998) and vegetation (Lathière et al., 2006), but with smaller contributions than oxidation. The major sinks of HCHO include oxidation by $\mathrm{OH}$, two photolysis reactions, and dry and wet depositions.

Through its production and loss in the troposphere, $\mathrm{HCHO}$ is a key species in the oxidation chain of methane and of NMVOC, and can modulate the budget of carbon monoxide (CO). However, very large uncertainties remain for the relative contributions of these different sources and sinks to the HCHO budget, particularly for the atmospheric production by NMVOC. This is mainly explained by the diversity of NMVOC, by their lifetimes varying from hours to weeks, and by the large spatio temporal variability of their emissions, leading to large uncertainties for the bottom-up estimates (that are based on emission factors or biogeochemical 
models). Various studies of the global budget of isoprene emissions, which account for about half of the total NMVOC biogenic source (Guenther et al., 1995), show large discrepancies among the bottom-up estimates: the Intergovernmental Panel on Climate Change (IPCC) Working Group on Atmospheric Chemistry and Greenhouse Gases (Ehhalt and Prather, 2001) estimates the isoprene source to $220 \mathrm{Tg} \mathrm{yr}^{-1}$, whereas it is 3 times higher in Guenther et al. (2006) with $500-750 \mathrm{Tg} \mathrm{yr}^{-1}$. Closing the formaldehyde budget is crucial for our understanding of the tropospheric chemistry and for the improvement of emission inventories of $\mathrm{HCHO}$ and its precursors.

Complementary to bottom-up estimates, atmospheric inversion infers sources and sinks of atmospheric species by statistically tracing back atmospheric signals given by concentration observations to the origin of emissions. It has played an important part during the last decade in the study of $\mathrm{CH}_{4}$ (e.g. Dentener et al., 2003; Bousquet et al., 2006; Bergamaschi et al., 2009) and CO (Pétron et al., 2004; Pfister et al., 2004; Heald et al., 2004; Tanimoto et al., 2008; Kopacz et al., 2010; Yurganov et al., 2010). Although chemically coupled, the sources and sinks of these trace gases have often been optimized independently from each other. Alternatively, Stavrakou and Müller (2006) have optimized CO emissions by taking into account their relation to NMVOC and $\mathrm{HCHO}$ through $\mathrm{OH}$. Butler et al. (2005) performed a simultaneous mass balance inversion of $\mathrm{CH}_{4}$ and $\mathrm{CO}$ emissions at a low spatial resolution. Pison et al. (2009) implemented the Simplified Atmospheric Chemistry System (SACS) in a variational inversion system and demonstrated the feasibility of a multi-species inversion, inferring simultaneously $\mathrm{CH}_{4}, \mathrm{OH}, \mathrm{H}_{2}$, and $\mathrm{CO}$ sources and sinks. However, these first studies did not use any HCHO observations. Indeed, large disagreements exist between the various measurement techniques employed for measuring $\mathrm{HCHO}$ mixing ratios (spectroscopic, chromatographic, and fluorimetric) (Hak et al., 2005). As a result, there is not yet a consistent global measurement network for $\mathrm{HCHO}$ as it exists for greenhouse gases or other air pollutants such as $\mathrm{CO}, \mathrm{CH}_{4}$ and ozone.

These limitations on the spatial coverage of the $\mathrm{HCHO}$ measurements can now be addressed by using $\mathrm{HCHO}$ total columns retrieved by satellite, which offer the unique possibility of sensing atmospheric $\mathrm{HCHO}$ at a global scale. Even though uncertainties remain large for the HCHO satellite retrievals, past studies have demonstrated the usefulness of HCHO column data (determined in near-UV wavelengths 310-365 nm) from the Global Ozone Monitoring Experiment (GOME) (Abbot et al., 2003; Palmer et al., 2006, 2007; Fu et al., 2007; Barkley et al., 2008), from the SCanning Imaging Absorption spectroMeter for Atmospheric CartograpHY (SCIAMACHY) (Stavrakou et al., 2009) and from the Ozone Monitoring Instrument (OMI) (Millet et al., 2008; Marais et al., 2012) to constrain NMVOC emissions, the latter having the highest spatial resolution of these 3 instruments.
In this paper, we extend the preliminary work of Pison et al. (2009), Chevallier et al. (2009) and Fortems-Cheiney et al. (2011), and present the first inversion study combining several satellite datasets to constrain the $\mathrm{HCHO}$ budget within the same inversion framework for the years 20052010. We simultaneously combine: (i) OMI HCHO columns, (ii) MOPITT $\mathrm{CO}$ mixing ratios at $700 \mathrm{hPa}$, (iii) $\mathrm{CH}_{4}$ concentrations from the surface networks, and (iv) methyl chloroform (MCF) concentrations from the surface networks to constrain OH radicals (Prinn et al., 2001; Krol and Lelieveld, 2003; Bousquet et al., 2005). This study provides an analysis of the global and regional $\mathrm{HCHO}$ budget, with a particular focus on HCHO atmospheric production by NMVOC. In Sect. 2, the OMI and MOPITT satellite retrievals, and the surface measurements are briefly presented. Our chemicaltransport model (described in Sect. 3) is forced by a complex flux scenario and used within an atmospheric inversion technique to optimize $\mathrm{HCHO}$ sources and sinks against the ensemble of remote and surface data. The main characteristics of the inversion system are summarized in Sect. 4. Section 5 gives the results of the inversion and explores their main features in terms of $\mathrm{HCHO}$ budget and implications for the other species $\left(\mathrm{OH}, \mathrm{CO}\right.$ and $\left.\mathrm{CH}_{4}\right)$. The inverted $\mathrm{HCHO}$ and $\mathrm{CO}$ sources are evaluated by comparison of the optimized and prior concentrations with independent (i.e. not used in the inversion) measurements from aircraft campaigns (INTEX-B, AMMA) and at the surface (NOAA/ESRL, AGAGE, CSIRO, EMPA, SAWS, NIWA and JMA/MRI).

\section{Atmospheric constraints}

\subsection{OMI HCHO retrieved columns}

The Ozone Monitoring Instrument (OMI) was launched aboard EOS Aura in July 2004. It has been flying on a $705 \mathrm{~km}$ sun-synchronous orbit that crosses the Equator at 13:38 LT. OMI is a near-UV/Visible nadir solar backscatter spectrometer covering the spectral range $270-500 \mathrm{~nm}$ with a resolution of $0.45 \mathrm{~nm}$ between 310 and $365 \mathrm{~nm}$. Its large swath of about $2600 \mathrm{~km}$ provides daily global coverage, with a spatial resolution of $13 \times 24 \mathrm{~km}$ at nadir, increasing substantially across-track to give an average cross-track spatial resolution of $\sim 43 \mathrm{~km}$. Measured trace gases include $\mathrm{O}_{3}, \mathrm{NO}_{2}, \mathrm{SO}_{2}$, $\mathrm{HCHO}, \mathrm{BrO}$, and $\mathrm{OClO}$ (Levelt et al., 2006).

The level 2 data of OMI HCHO Version 3 total columns that we used have been collected from http://mirador.gsfc. nasa.gov/. The data selection follows the criteria of the data quality statement (NASA, 2008): only column values flagged as "good" in the product were included. Also, data with cloud fraction higher than 0.2 were excluded, as recommended by Millet et al. (2006), who showed that the bias on HCHO retrievals decreases with decreasing cloud fraction (from $14 \%$ at a cloud fraction of 0.4 to $6 \%$ at a cloud fraction of 0.2 ). Similarly, only retrievals between $65^{\circ} \mathrm{S}$ and $65^{\circ} \mathrm{N}$ were used 
in this study. Outliers (column $>1.0 \times 10^{+19}$ molec $\mathrm{cm}^{-2}$ ) were also removed. OMI retrievals are affected by an artificial drift, connected to an increase in detector dark current observed over OMI lifetime, from $2.72 \times 10^{+15}$ molec cm $\mathrm{cm}^{-2}$ in December 2004 to $8.05 \times 10^{+15} \mathrm{molec} \mathrm{cm}^{-2}$ in December 2010. We have applied the empirical correction developed by the data providers. It should be noted that the total uncertainties of individual HCHO column retrievals typically range within $50-105 \%$, with the lower end of this range over HCHO hotspots (Kurosu, 2008).

Due to the scarcity of in situ HCHO measurements, opportunities for validation have been so far limited. The OMI HCHO columns have been evaluated against GOME retrievals by Millet et al. (2008) for the North American region. This study indicates a reasonable agreement between the two datasets: the OMI spatial distribution is similar to that observed by GOME in previous years (differences of 2-14\%), and OMI seems to exhibit less retrieval noise (as seen in their Fig. 2). Boeke et al. (2011) compared OMI HCHO columns to aircraft data over the USA, Mexico, and the Pacific, and found an average bias of less than $3 \%$.

\subsection{MOPITT-V4 CO retrieved mixing ratios}

The Measurements Of Pollution In The Troposphere (MOPITT) instrument was launched aboard EOS Terra in December 1999 and has been operating nearly continuously since March 2000. This spectrometer flies on a sun-synchronous orbit that crosses the Equator at 10:30 and 22:30 LT. The spatial resolution of its observations is about $22 \mathrm{~km}$ at nadir. Three days of measurements are needed to achieve global coverage with its $640-\mathrm{km}$ swath.

The Level 2 data of MOPITT Version 4 have been collected from http://reverb.echo.nasa.gov/. They include CO mixing ratios at 10 standard pressure levels between the surface and $150 \mathrm{hPa}$ for cloud-free spots. As a trade-off between data volume, closeness to the surface and retrieval noise, only the $700 \mathrm{hPa}-l e v e l \mathrm{CO}$ retrievals together with their associated averaging kernels (AK) were used here. Data within $25^{\circ}$ from the poles have been left out, as the weight of the a priori $\mathrm{CO}$ profile in the MOPITT retrievals increases towards the pole. MOPITT's thermal band radiances are more sensitive to surface emissivity at night than during the day, and consequently less sensitive to the $\mathrm{CO}$ distribution at night (Crawford et al., 2004). Therefore, the CO retrieval errors are larger at night than during the day, and is why the nighttime observations have been excluded.

MOPITT retrievals have been evaluated on a regular basis since the start of the mission in 2000, and have been compared against aircraft measurements (made during the NASA INTEX-A, NASA INTEX-B and NSF MIRAGE field campaigns), as well as the long-term record from NOAA observations and the MOZAIC experiment (Emmons et al., 2004, 2007, 2009). Retrieval errors are estimated to be about $10 \%$ for each retrieval, with regional biases of a few parts per bil- lion. The MOPITT retrievals suffer from a time-varying bias in Version 4 (Deeter et al., 2010), as in Version 3 (Yurganov et al., 2008; Emmons et al., 2009; Drummond et al., 2009). This positive bias drifts by about $0.5 \mathrm{ppbv} \mathrm{yr}^{-1}$, on average at $700 \mathrm{hPa}$, in Version 4 (Deeter et al., 2010). This positive bias drift is not taken into account in our observation error and may bias the inversion estimate. Nevertheless, the consistency of the MOPITT-based inverted fluxes with the IASIbased ones showed that the impact of the drift in the MOPITT retrievals is negligible (Fortems-Cheiney et al., 2011).

\subsection{Methane and methyl chloroform surface observations}

$\mathrm{CO}, \mathrm{HCHO}, \mathrm{CH}_{4}$ and $\mathrm{OH}$ concentrations are chemically related. $\mathrm{OH}$ is an essential modulator of this reaction chain, but this short-lived compound ( $\sim 1 \mathrm{~s})$ is not easy to constrain in a global atmospheric model. Our approach uses methyl chloroform $\left(\mathrm{CH}_{3} \mathrm{CCl}_{3}\right.$ or MCF) as a proxy tracer (Krol and Lelieveld, 2003; Prinn et al., 2005; Bousquet et al., 2005). MCF only reacts with $\mathrm{OH}$ and its sources and sinks (emissions, photolysis, ocean sink) are assumed to be quantified with a rather good accuracy. During the target period of this study (2005-2010), Montzka et al. (2011) showed that the MCF proxy method gives comparable results to CTMs for $\mathrm{OH}$ variations. Here, $\mathrm{OH}$ monthly 3-D fields are optimized in four latitudinal volumes using a prior spatio-temporal distribution of $\mathrm{OH}$ derived from a full chemistry climate model (Hauglustaine et al., 2004).

$\mathrm{CH}_{4}$ in situ measurements are also used to constrain methane emissions. A set of stations that measured MCF and $\mathrm{CH}_{4}$, daily or nearly continuously for the 2005-2010 period, has been selected from the AGAGE and NOAA/ESRL networks available on the World Data Center for Greenhouse Gases site (WDCGG, http://ds.data.jma.go.jp/gmd/wdcgg/).

\section{The LMDz-SACS chemistry transport model}

LMDz-SACS is a global 3-D chemistry transport model (CTM) coupling an offline version of the atmospheric general circulation model LMDz (Hourdin et al., 2006) with the atmospheric chemistry module SACS (Simplified Atmospheric Chemistry System) (Pison et al., 2009). To minimize the computational cost of the inversions, we use a pre-calculated archive of 3-hourly transport mass fluxes instead of running the full general circulation model LMDz. The archive has been obtained from a previous simulation of LMDz for the same dates, guided by the horizontal winds from ECMWF reanalyses. The horizontal resolution is $3.75^{\circ} \times 2.75^{\circ}$ and the vertical resolution includes 19 sigma-pressure levels (first level thickness of about $150 \mathrm{~m}$, resolution in the boundary layer of 300 to $500 \mathrm{~m}$ and $\approx 2 \mathrm{~km}$ at tropopause). SACS is a very simplified version of INCA (INteraction Chimie Aérosols, Hauglustaine et al., 2004; 
Folberth et al., 2006) that consists in solving the chemical interaction between a limited set of four species, which represents the oxidation chain of methane: $\mathrm{CH}_{4}, \mathrm{HCHO}, \mathrm{CO}$, and $\mathrm{OH}$. The HCHO production and loss in the system are described with the following reactions:

$$
\begin{aligned}
& \mathrm{CH}_{4}+\mathrm{OH} \rightarrow \mathrm{HCHO} \\
& k=2.45 \times 10^{-12} \exp (-1775 / T) \mathrm{cm}^{3} \mathrm{molec}^{-1} \mathrm{~s}^{-1} \\
& \mathrm{CH}_{4}+\mathrm{O}^{1} \mathrm{D} \rightarrow \mathrm{HCHO}+\mathrm{H}_{2} \\
& k=3.75 \times 10^{-11} \mathrm{~cm}^{3} \mathrm{molec}^{-1} \mathrm{~s}^{-1} \\
& \mathrm{HCHO}+\mathrm{OH}\left(+\mathrm{O}_{2}\right) \rightarrow \mathrm{HO}_{2}+\mathrm{CO}+\mathrm{H}_{2} \mathrm{O} \\
& \quad k=1.50 \times 10^{-13} \exp (1.06 P / P o) \mathrm{cm}^{3} \mathrm{molec}^{-1} \mathrm{~s}^{-1} \\
& \mathrm{HCHO}+h v\left(+\mathrm{O}_{2}\right) \rightarrow \mathrm{H}_{2}+\mathrm{CO} \\
& J \text { precomputed by } \mathrm{INCA} \\
& \mathrm{HCHO}+h v\left(+\mathrm{O}_{2}\right) \rightarrow 2 \mathrm{HO}_{2}+\mathrm{CO} \\
& J \text { precomputed by INCA }
\end{aligned}
$$

The prior sources and sinks of formaldehyde, entering or calculated by LMDz-SACS, are summarized in the schematic Fig. 1a), which also depicts part of the SACS mechanism. Averaged over the 6-yr period, the prior photochemical destruction of HCHO is $1210 \mathrm{TgHCHO} \mathrm{yr}^{-1}$ and the surface

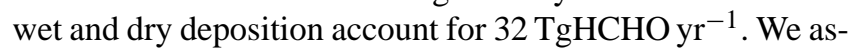
sume that methane is oxidized into $\mathrm{HCHO}$ in a single step, thereby neglecting the formation of methyl hydroperoxide under low $\mathrm{NO}_{\mathrm{x}}$ conditions, which can delay or slightly reduce the HCHO atmospheric production. The global prior $\mathrm{HCHO}$ atmospheric production is $1332 \mathrm{TgHCHO} \mathrm{yr}^{-1}$, with

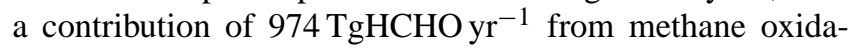

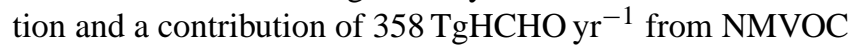
oxidation. Indeed, in addition to the photochemical reactions shown above, the source of HCHO from the degradation of NMVOC is prescribed in SACS. This 3-D production of formaldehyde is obtained from a previous simulation of the full atmospheric chemistry model LMDzINCA using NMVOC emissions and chemistry of Folberth et al. (2006). In this full-chemistry simulation, the anthropogenic NMVOC emissions were those from the Emission Database for Global Atmospheric Research (EDGAR-v3.2, http://edgar.jrc.ec.europa.eu) database valid for 1995 (Olivier and Berdowski, 2001); the biogenic NMVOC and formaldehyde emissions were taken from the Global Emissions Inventory Activity (GEIA) database (Guenther et al., 1995). Biomass burning emissions were from the interannual Global Fire and Emission database GFED-v2 (van der Werf et al., 2006) (http://www.globalfiredata.org/).

The sources of the other species, $\mathrm{CO}$ and $\mathrm{CH}_{4}$, including industry and fossil fuel combustion, are drawn from the EDGAR-v3.2 and from GFED-v2 inventories. The emissions of $\mathrm{CH}_{4}$ due to wetlands and termites are based on the study of Fung et al. (1991). It should be noted that we did not adapt the 1995 EDGAR-v3.2 inventory to the 2000s. We choose EDGAR-v3.2 rather than the recent EDGAR-v4.2 for consistency with the study of Fortems-Cheiney et al. (2011).
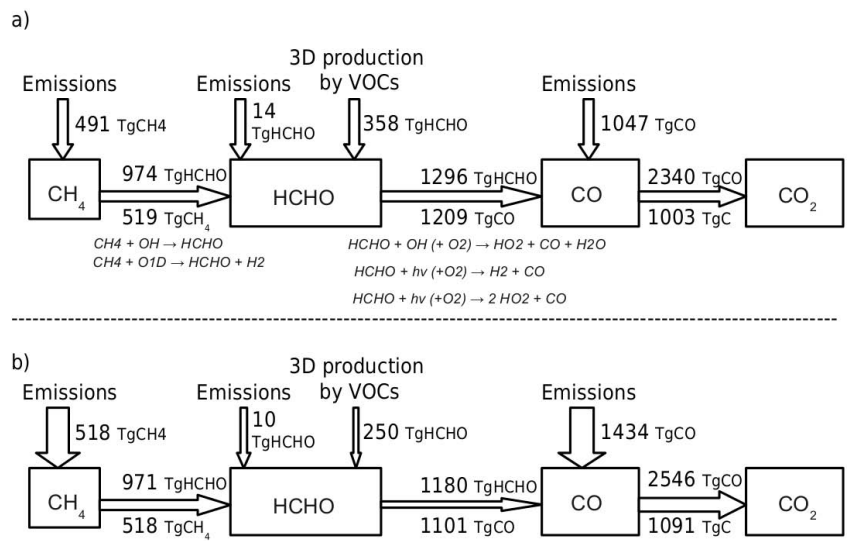

Fig. 1. Prior (a) and posterior (b) $\mathrm{HCHO}$ sources and sinks in the SACS mechanism. Sinks of $\mathrm{H}_{2}$ and the HCHO deposition are included in SACS but not displayed. Changes of arrow thickness between prior and posterior indicate a reduction or an increase of the sources and sinks. Values are for year 2006.

\section{The inverse model}

Our inverse problem consists in optimizing the 3-D atmospheric production of formaldehyde, the surface emissions of $\mathrm{CO}$ and $\mathrm{CH}_{4}$, and $\mathrm{OH}$ concentrations within the same inversion. We apply the inverse method described by Chevallier et al. (2005, 2007). This inversion scheme uses the LMDzSACS adjoint model developed by Pison et al. (2009). The optimal solution (in a statistical sense) is found by iteratively minimizing the following cost function:

$$
\begin{aligned}
& J(\boldsymbol{x})=\left(\boldsymbol{x}-\boldsymbol{x}_{b}\right)^{T} \mathbf{B}^{-1}\left(\boldsymbol{x}-\boldsymbol{x}_{b}\right)+(H(\boldsymbol{x})-\boldsymbol{y})^{T} \\
& \mathbf{R}^{-1}(H(\boldsymbol{x})-\boldsymbol{y}),
\end{aligned}
$$

where $\boldsymbol{x}$ is the state vector that contains the variables to be optimized by the inversion:

- $\mathrm{CO}, \mathrm{CH}_{4}$, and MCF surface emissions at a $3.75^{\circ} \times 2.5^{\circ}$ (longitude, latitude) resolution.

- $\mathrm{CO}, \mathrm{CH}_{4}$, and MCF 3-D initial conditions at an 8-day and at a $3.75^{\circ} \times 2.5^{\circ}$ resolution.

- 2-D factors to scale the 3-D-chemical production of $\mathrm{HCHO}$ (due to NMVOC) at an 8 -day and $3.75^{\circ} \times 2.5^{\circ}$ resolution.

- 4 factors to scale the $\mathrm{OH}$ atmospheric concentrations for each 8-day period within four latitude bands $\left(90-30^{\circ} \mathrm{S}\right.$, $30^{\circ} \mathrm{S}-0,0-30^{\circ} \mathrm{N}, 30-90^{\circ} \mathrm{N}$ ).

The prior information $\boldsymbol{x}_{b}$ is a combination of the datasets EDGAR-v3.2, GFED-v2 and GEIA, as described in Sect. 3. The error statistics have been detailed in Fortems-Cheiney et al. (2011) and their main features are recalled here. The covariance matrix $\mathbf{B}$ of the prior errors is defined as diagonal. The error standard deviations assigned to the $\mathrm{CO}$ prior 


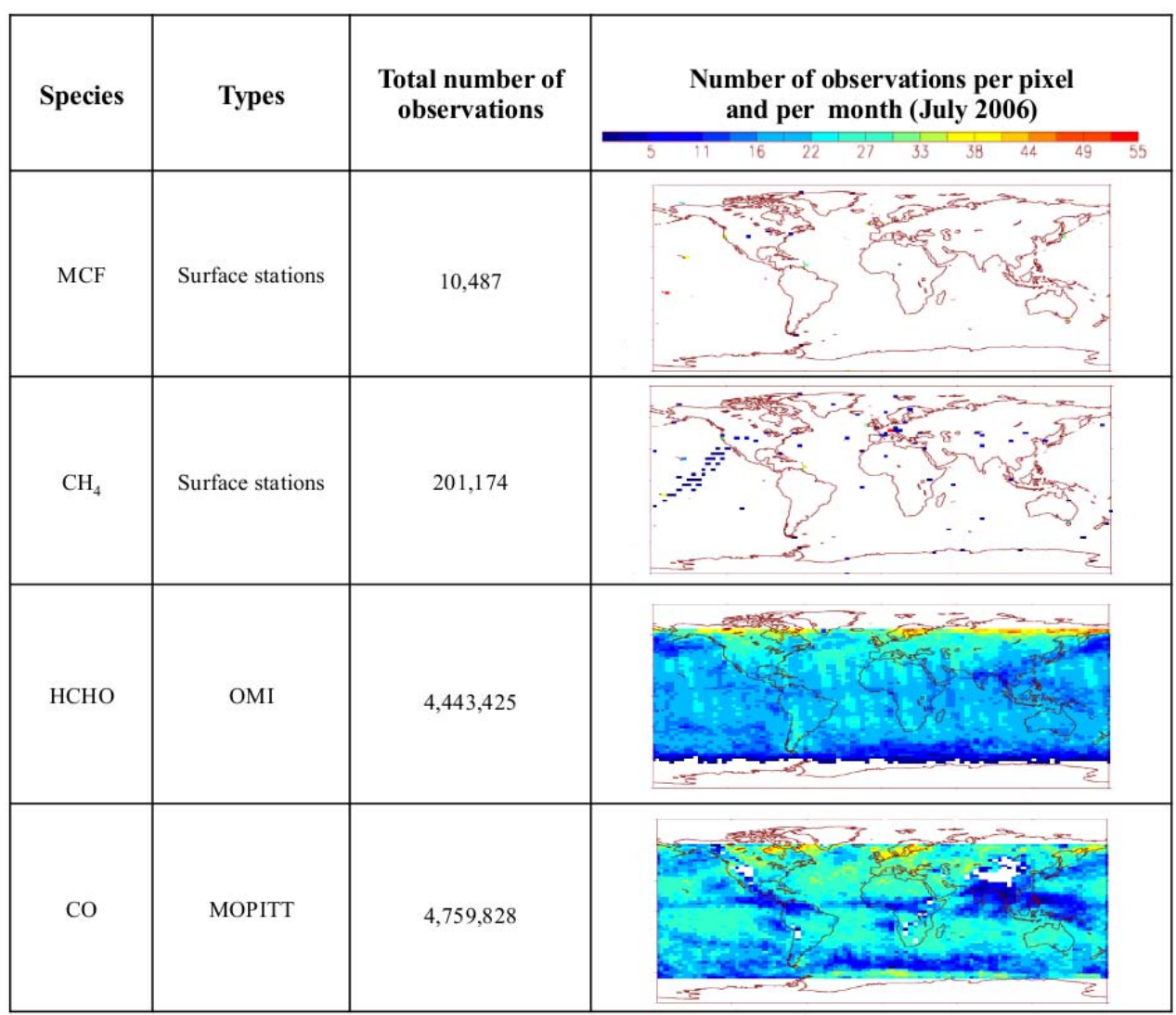

Fig. 2. Summary of the observations used in the inversion: total number of observations over the 2005-2010 time period and typical distributions of these observations on the right for July 2006.

emissions in the covariance matrix $\mathbf{B}$ are set at $100 \%$ of the maximum value of the emission time series during the corresponding year for each grid point. The choice of a relatively large value accounts for uncertainties in the seasonal cycle of particular emissions, such as fires (Chevallier et al., 2009). Given the large discrepancies associated with the biogenic NMVOC estimates (i.e. between IPCC, 2001 and Guenther et al., 2006), errors assigned to the scaling factors of the 3 -D-chemical production of $\mathrm{HCHO}$ are set to $400 \%$. For MCF emissions, the EDGAR-v3.2 inventory by Olivier et al. (2001) has been adapted to give estimates of MCF emissions over our time period (2005-2010) by applying an exponential decrease (update of Bousquet et al., 2005). As MCF emissions are well known, errors are set to $1 \%$ of the flux for MCF. The errors assigned to the scaling factor of $\mathrm{OH}$ are set to $10 \%$, based on the differences seen between various estimates of OH concentrations (Prinn et al., 2001; Krol and Lelieveld, 2003; Bousquet et al., 2005). Finally, errors are set to $100 \%$ of the flux for $\mathrm{CH}_{4}$. Several sensitivity tests associated with these prior settings are presented in Sect. 6 .

For the initial conditions, errors are set to $10 \%$ for $\mathrm{HCHO}$ and MCF and to only $3 \%$ for $\mathrm{CH}_{4}$ and $5 \%$ for CO. Spatial correlations are defined by an e-folding length of $500 \mathrm{~km}$ over land and $1000 \mathrm{~km}$ over sea, without any correlation between land and ocean grid points. Temporal correlations are neglected.

The observations vector $\boldsymbol{y}$ used for the inversion are surface observations of MCF and $\mathrm{CH}_{4}$, as well as satellite retrievals from MOPITT for CO, and from OMI for HCHO (see Sect. 2), both averaged into "super-observations" at the $3.7^{\circ} \times 2.75^{\circ}$ resolution of LMDz-SACS, amounting to about 9.5 million for the 2005-2010 time period (see the distribution in Fig. 2). For MOPITT, as the averaging kernel (AK) profiles do not vary much within the grid cell, we use the AK profile of the first retrieval when several of them are averaged into a super-observation. No averaging kernels are available for the OMI product; the calculation of HCHO columns is performed as a mean, weighted by the relative thickness of model pressure layers.

Error correlations between the super-observations are neglected, so that the covariance matrix $\mathbf{R}$ of the observation errors is diagonal (i.e. only variances are taken into account). The diagonal R-matrix representing observation errors is filled with variances which combine representation errors (e.g. the mismatch between the observation and model resolutions), errors of the observation operator (including 


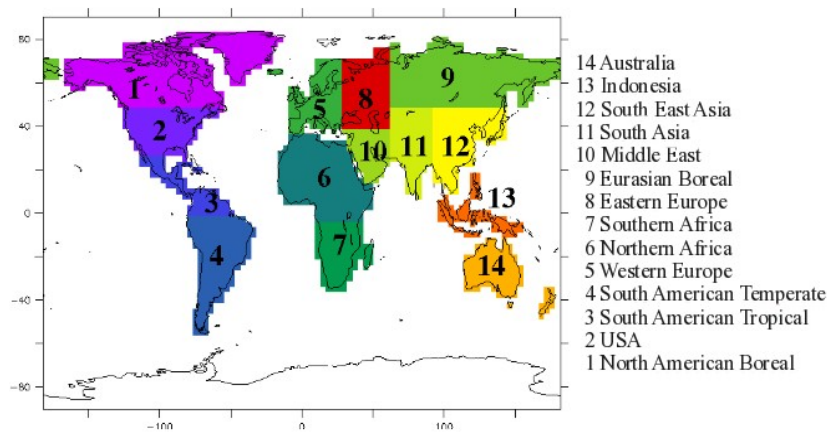

Fig. 3. Definition of the 14 regions used in this study.

transport and chemical-scheme errors in LMDZ-SACS) and measurements errors. The errors of the observation operator and the representation error are difficult to estimate precisely. LMDz-SACS accumulates the errors of the reference model LMDz-INCA, complemented by those due to the simplifications made in the chemical scheme. As a consequence, we chose to define the variance of the individual observation errors in $\mathbf{R}$ as the quadratic sum of the measurement error reported in the MOPITT and the OMI data sets, and of the CTM errors set to $50 \%$ of the retrieval values following Pison et al. (2009).

The 6-yr period considered here is processed in a single inversion. The presence of $\mathrm{OH}$ among the optimized variables makes the $H$ operator diverge from linearity and makes the cost function $J$ diverge from quadracity. In this context, the cost function and the norm of its gradient are minimized with the quasi-Newton minimization algorithm M1QN3 (Gilbert and Lemaréchal, 1989), and our system is adapted to deal with non-linearities. After 28 iterations, corresponding to 5 weeks of calculation on 8 processors, the norm of the gradient of the cost function is reduced by $98 \%$. More iterations do not further reduce the norm of the gradient.

As described by Chevallier et al. (2007), it is possible to rigorously compute the uncertainty of the inverted fluxes by a Monte-Carlo approach. Because of its large computational expense, the computation of the uncertainty on the inverted fluxes was performed for year 2006 only. This results in a statistical ensemble of 48 realizations of weekly fluxes, in which the prior and the observations follow their respective error statistics. This ensemble allows computing the flux uncertainty reduction up to the monthly scale. Here, the monthly flux uncertainty reduction is assumed to be about the yearly flux uncertainty reduction for $\mathrm{HCHO}$ and for $\mathrm{CO}$ because of the relatively short lifetime of these species, but this assumption does not hold for $\mathrm{CH}_{4}$, whose lifetime is about $12 \mathrm{yr}$ (IPCC, 2007). In the following, error bars will therefore be given for $\mathrm{HCHO}$ and for $\mathrm{CO}$ only.
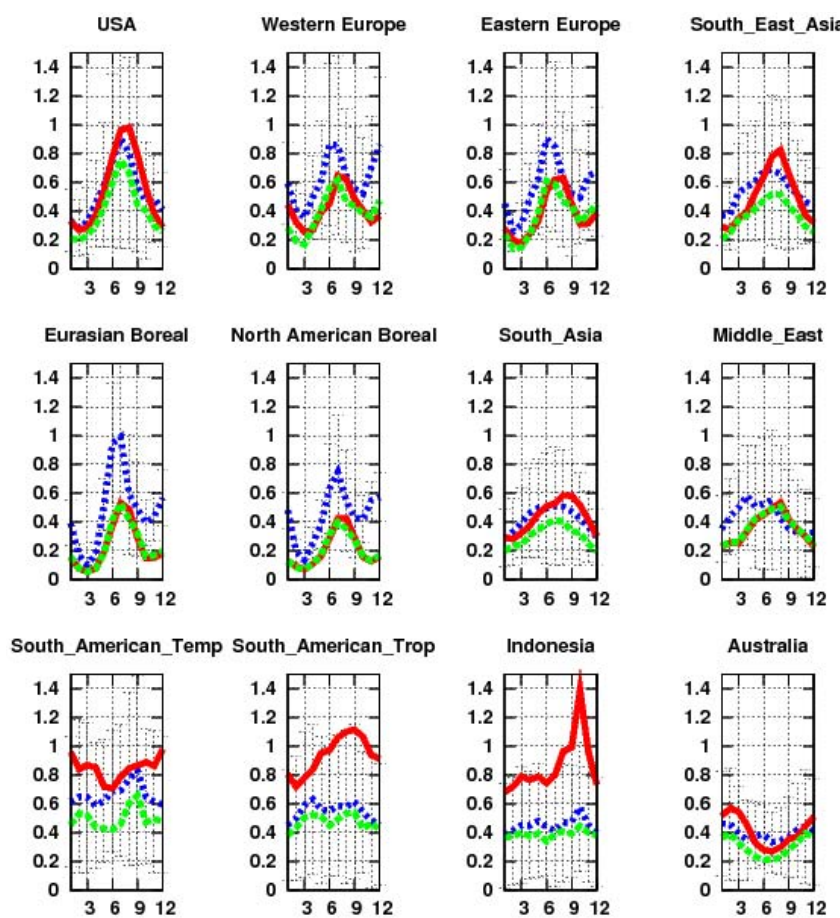

Indonesia
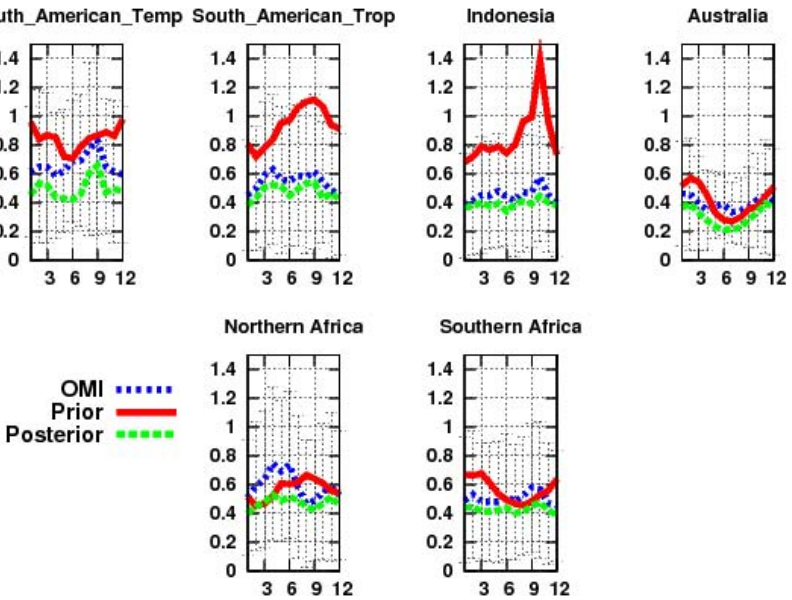

Fig. 4. Times series of monthly averaged formaldehyde total columns retrieved by OMI (in blue) and simulated by the model LMDz-SACS using the prior (in red) and the posterior fluxes (in green) for year 2006, from January to December. Error bars represent the OMI retrieval errors. Units are $10 \mathrm{e}^{16}$ molec $\mathrm{cm}^{-2}$.

\section{Results}

Figure 3 shows the 14 continental regions used to analyse our results.

\subsection{Prior and posterior HCHO total columns, and fit to OMI observations}

The OMI observations, the prior, and the posterior-modeled monthly mean global HCHO columns averaged over the 14 continental regions are shown in Fig. 4 for year 2006. The HCHO prior columns simulated by the model weakly agree with OMI observations, both in magnitude and in their seasonal cycle. Except over the two boreal and European regions, OMI measurements are smaller than the prior columns for the entire year. The largest discrepancies are found over the tropical regions, and particularly over South America and Indonesia. This has already been pointed out by Barkley et al. (2008), who found higher model HCHO 
Table 1. Total 3-D HCHO production by NMVOC for years 2005 to 2010 before inversion and after inversion, for 14 continental regions and for the globe in $\mathrm{TgHCHO} \mathrm{yr}^{-1}$. All budgets correspond to a 12-month period. The uncertainty of the inverted fluxes for 2006 are computed by a Monte-Carlo approach.

\begin{tabular}{|c|c|c|c|c|c|c|c|c|c|c|c|c|}
\hline & \multicolumn{2}{|c|}{2005} & \multicolumn{2}{|c|}{2006} & \multicolumn{2}{|c|}{2007} & \multicolumn{2}{|c|}{2008} & \multicolumn{2}{|c|}{2009} & \multicolumn{2}{|c|}{2010} \\
\hline & prior & post & prior & post & prior & post & prior & post & prior & post & prior & post \\
\hline North Am Boreal & 4 & 5 & $4 \pm 1$ & $4 \pm 1$ & 4 & 4 & 4 & 5 & 4 & 4 & 4 & 5 \\
\hline USA & 26 & 18 & $26 \pm 15$ & $20 \pm 12$ & 26 & 20 & 26 & 20 & 26 & 21 & 26 & 20 \\
\hline South Am Trop & 39 & 19 & $39 \pm 19$ & $18 \pm 15$ & 39 & 19 & 39 & 18 & 39 & 21 & 39 & 25 \\
\hline South Am Temp & 80 & 55 & $77 \pm 25$ & $54 \pm 10$ & 77 & 54 & 81 & 54 & 81 & 55 & 81 & 67 \\
\hline Northern Africa & 50 & 37 & $49 \pm 29$ & $34 \pm 25$ & 49 & 34 & 50 & 36 & 50 & 38 & 50 & 36 \\
\hline Southern Africa & 29 & 21 & $28 \pm 18$ & $20 \pm 18$ & 28 & 20 & 28 & 20 & 28 & 20 & 28 & 20 \\
\hline Western Europe & 9 & 9 & $9 \pm 5$ & $9 \pm 5$ & 9 & 9 & 9 & 8 & 9 & 9 & 9 & 9 \\
\hline Eastern Europe & 6 & 6 & $6 \pm 3$ & $6 \pm 3$ & 6 & 6 & 6 & 6 & 6 & 6 & 6 & 6 \\
\hline Eurasian Boreal & 5 & 5 & $5 \pm 1$ & $6 \pm 1$ & 5 & 6 & 5 & 5 & 5 & 6 & 5 & 5 \\
\hline Middle East & 3 & 3 & $3 \pm 2$ & $3 \pm 2$ & 3 & 3 & 3 & 3 & 3 & 3 & 3 & 3 \\
\hline South Asia & 18 & 11 & $18 \pm 9$ & $10 \pm 8$ & 18 & 10 & 18 & 12 & 18 & 12 & 18 & 11 \\
\hline South East Asia & 31 & 25 & $31 \pm 20$ & $24 \pm 19$ & 31 & 23 & 32 & 24 & 32 & 26 & 32 & 24 \\
\hline Indonesia & 24 & 9 & $28 \pm 5$ & $14 \pm 4$ & 28 & 14 & 23 & 12 & 23 & 19 & 23 & 22 \\
\hline Australia & 15 & 10 & $16 \pm 5$ & $11 \pm 4$ & 16 & 11 & 16 & 11 & 16 & 12 & 16 & 23 \\
\hline Globe & 358 & 248 & $358 \pm 58$ & $250 \pm 54$ & 358 & 250 & 358 & 252 & 358 & 269 & 358 & 276 \\
\hline
\end{tabular}

columns (using the GEOS-Chem chemistry-transport model and the MEGAN inventory for NMVOC emissions) than GOME HCHO measurements. HCHO concentrations are mainly driven by NMVOC emissions and the uncertainties associated with these NMVOC emissions (e.g. in the GEIA inventory, or in Model of Emissions of Gases and Aerosols MEGAN) are large (Barkley et al., 2008). These uncertainties result from errors in emission factors, and from incorrect or incomplete parameterizations of activity factors. For example, tropical rainforest emission in the GEIA inventory are based on ambient isoprene concentration measurements from a single study (Zimmerman et al., 1988; Barkley et al., 2008), which could explain the notable differences in terms of magnitude over tropical regions.

In tropical regions, except Indonesia, our prior does not reproduce the observed seasonal cycle, particularly over South America and Africa. It should be noted that the entire growing season of isoprene emission is represented by a single basal emission factor in GEIA inventory. Kuhn et al. (2004) found it inadequate for certain representative tropical plant species. This could explain the differences in terms of seasonality over tropical regions.

After optimization of the 3-D HCHO production, the model succeeds in capturing both the seasonal cycle and the magnitude of the concentrations. Indeed, Fig. 4 shows a better fit than between the posterior simulated columns and the observations compared to the prior ones over regions USA, South Asia, South East Asia, Australia, South American Temperate, South American Tropical and Indonesia. However, some discrepancies remain: for example, the model fails to reproduce the observed seasonal decrease from
July to October over North Africa. This could be explained by the relatively large OMI data uncertainties over this region (particularly over Sahara), reaching more than $250 \%$, which implies less deviation from prior fluxes as compared to regions with less uncertain data. The agreement for the two boreal regions is not as good as for other regions because OMI data north of $65^{\circ} \mathrm{N}$ are not used in the inversion.

\subsection{Optimization of the HCHO sources and sinks}

The optimization of the HCHO column implies changes in the HCHO sources and sinks (surface emissions, atmospheric production and atmospheric loss), which are displayed in Fig. 1b. We do not consider changes of the HCHO surface emissions in the following, as they are very small in magnitude compared to the atmospheric production and loss.

\subsubsection{Prior and posterior 3-D HCHO production by NMVOC}

As $\mathrm{HCHO}$ is produced by NMVOC oxidation, and as some NMVOC have sufficiently short lifetimes, there exists a relationship at local scale between the emission of NMVOC, their oxidation into $\mathrm{HCHO}$ and the observed $\mathrm{HCHO}$ column. As a result, the 3-D HCHO production by NMVOC is a good indicator for the emissions of short-lived NMVOC (Palmer et al., 2003). The prior and posterior $\mathrm{HCHO}$ productions by NMVOC are shown in Table 1 and in Fig. 5.

The posterior global 6-yr average $\mathrm{HCHO}$ production by NMVOC is estimated at $257 \mathrm{TgHCHO} \mathrm{yr}^{-1}$, about $28 \%$

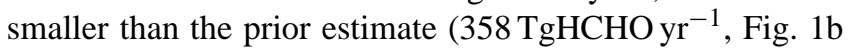
and Table 1). All regions contribute to this decrease but the 


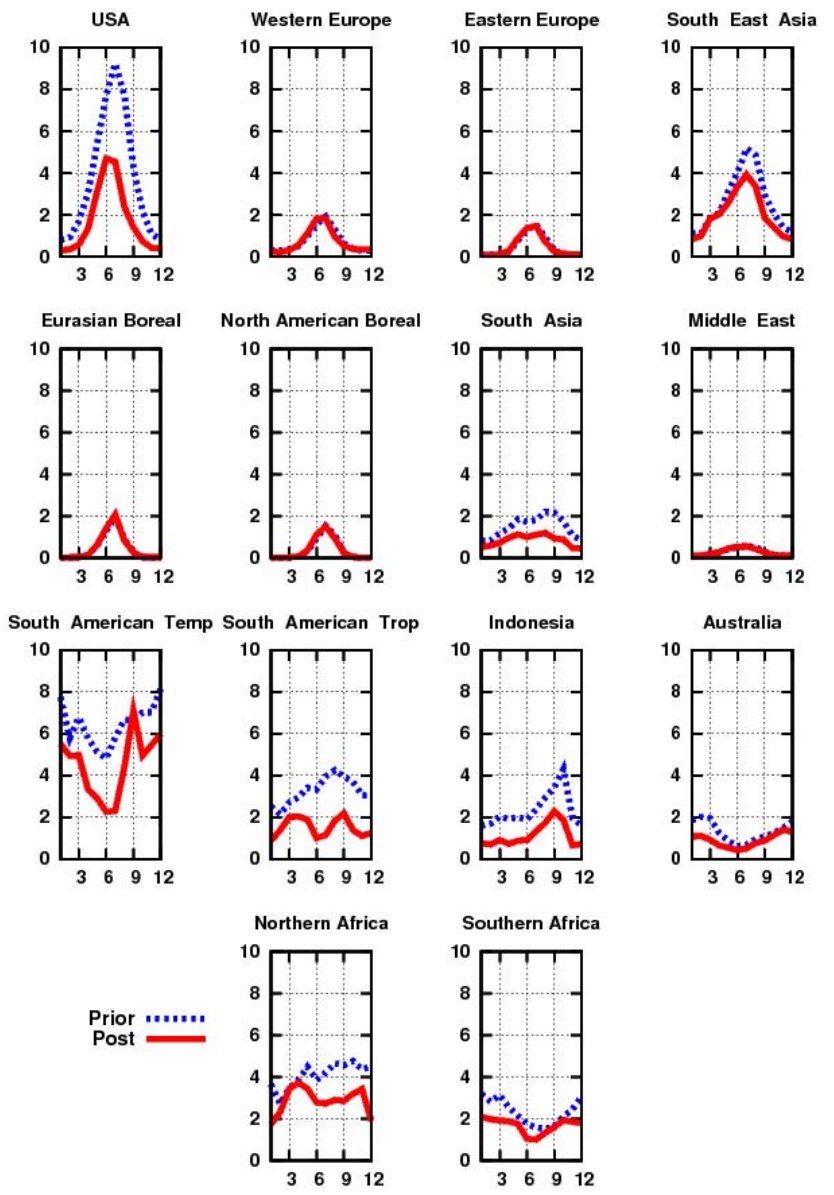

Fig. 5. Times series of prior (in blue) and posterior (in red) HCHO 3-D production by NMVOC for year 2006. Units are TgH$\mathrm{CHO} /$ month.

changes are smaller for Europe, Middle East and for the two boreal regions. The main changes are seen over regions of high NMVOC emissions (De Smedt et al., 2008): the USA and South Asia in the Northern Hemisphere, and all tropical regions. We discuss our results for these particular regions in the following.

\section{Regional budget and comparison with recent studies}

The annual posterior 3-D HCHO production by NMVOC is decreased by $26 \%$ over the USA, from $26 \mathrm{TgHCHO}$ to $19 \mathrm{TgHCHO}$ on the 6-yr average. As seen in Fig. 5, this decrease only affects the summer months, dominated by enhanced isoprene emissions. Indeed, recent studies (Abbot et al., 2003; Palmer et al., 2003, 2006; Müller et al., 2008) showed that the variability of the HCHO columns over North America reflects the emissions of NMVOC precursors, and particularly isoprene. Consequently, our results suggest a large overestimation of isoprene emissions over the USA in the GEIA inventory. This is in agreement with the study of Stavrakou et al. (2009). They evaluated the accuracy of

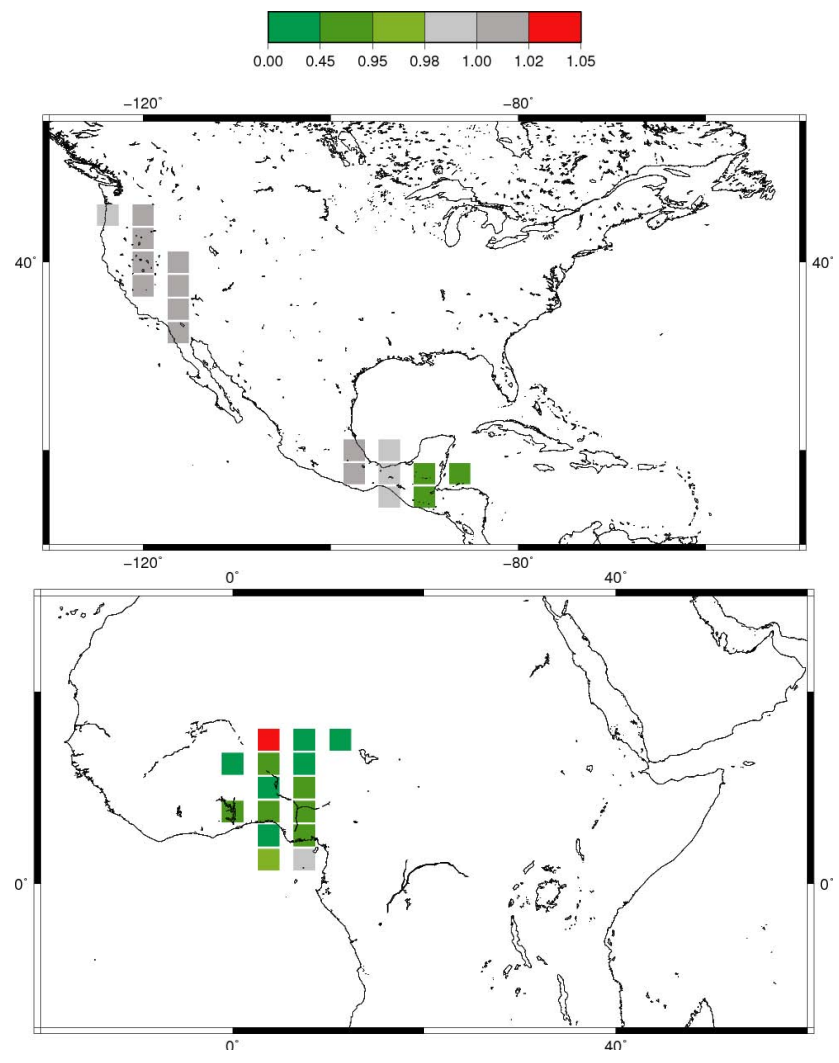

Fig. 6. Ratio of the posterior to the prior values of bias (in absolute value) between simulated and observed concentrations for the INTEX-B (top) and AMMA campaigns (bottom). The inversion improves the simulation when the ratio of the absolute bias is less than 1 (in green).

the GEIA biogenic emission inventory $\left(502 \mathrm{Tg} \mathrm{yr}^{-1}\right.$ for isoprene, $127 \mathrm{Tg} \mathrm{yr}^{-1}$ for terpenes, as used in this study) and the Model of Emissions of Gases and Aerosols MEGANECMWF (Müller et al., 2008) against a new dataset of spaceborne HCHO columns derived from GOME and SCIAMACHY. When they halved the isoprene emissions of the MEGAN-ECMWF inventory over North America (similar to the GEIA's inventory in this particular region), they obtained a significant reduction of their observation to model bias (from 37.2 to $7.6 \%$ ). Also, the isoprene emissions inferred by Palmer et al. (2003) from the GOME data are $20 \%$ less than those of GEIA. Shim et al. (2005) recently inverted global isoprene emissions for various ecosystems from September 1996 to August 1997 using the GOME formaldehyde measurements. They found isoprene emission budgets $14 \%$ smaller than those of GEIA over the USA, with a reduction for particular ecosystems (grass/shrub, dry evergreen, crop/woods, and the regrowing woods).

In South Asia, the posterior 3-D HCHO production by NMVOC is almost half the prior, estimated at $11 \mathrm{TgHCHO}$ compared to the prior $18 \mathrm{TgHCHO}$. Figure 5 shows that the prior and the posterior HCHO production by NMVOC are in 
a reasonable agreement in January and in December for this region when the most abundant source is attributed to anthropogenic activities and particularly to strong domestic heating (Fu et al., 2007). However, for the rest of the year, the posterior $\mathrm{HCHO}$ source from NMVOC is significantly smaller than the prior one. Also, the HCHO production by NMVOC is decreased during the growing season, from April to October. This feature also points to an overestimation of the biogenic NMVOC emission, such as isoprene, in the GEIA inventory. In Indonesia, the posterior 3-D HCHO production by NMVOC is largely decreased by the inversion $(-54 \%)$, from 26 to $12 \mathrm{TgHCHO}$ on the 6-yr average.

The African continent has a posterior 3-D HCHO production by NMVOC of $54 \mathrm{TgHCHO}$ ( $34 \mathrm{TgHCHO}$ for Northern Africa and $20 \mathrm{TgHCHO}$ for Southern Africa), $36 \%$ smaller than the prior one. This value is in agreement with the study of Marais et al. (2012), who inferred isoprene emissions from HCHO OMI satellite data and applied it to the African continent: they found total OMI-derived isoprene emissions $22 \%$ smaller than MEGAN (60 vs. $77 \mathrm{TgC} \mathrm{yr}^{-1}$ ), and concluded that isoprene emissions are overestimated over the central African rainforest in their prior inventory.

Finally, the inverse modeling results also suggest a much lower HCHO production by NMVOC for regions South American Tropical and South American Temperate, by respectively $51 \%$ and $31 \%$. Their total posterior HCHO production by NMVOC sources is 19 and $54 \mathrm{TgHCHO}$ on the 6yr average. In these two regions, it is difficult to separate the biomass burning and biogenic NMVOC contributions to the observed HCHO signal. However, it can be noticed that Shim et al. (2005) found posterior isoprene emissions $30 \%$ smaller than the corresponding GEIA estimate for South America, with a large reduction of the tropical rain forest emissions. The MEGAN-ECMWF biogenic fluxes averaged over the 1997-2011 period are also lower than the GEIA inventory by $40 \%$ (62 vs. $87 \mathrm{TgC} \mathrm{yr}^{-1}$ ) (Stavrakou et al., 2009).

\section{Seasonality and interannual variability}

Figure 5 shows the time series of the prior and posterior monthly 3-D HCHO production by NMVOC in each region. There are some interesting differences in seasonality between prior and posterior cycles. Over tropical regions (except Indonesia), the optimization dramatically changes the seasonal cycle. For example, the posterior cycles over Northern Africa present two peaks (in September and in April) in both the wet and dry seasons, with highest values during the dry season. Over region South American Tropical, instead of peaking at 4.2 TgHCHO in August only like the prior, the posterior estimates peak at $2 \mathrm{TgHCHO}$ in April (wet season) and at 2.1 TgHCHO in September (dry season). Interestingly, this posterior seasonal cycle agrees well with the in-situ tower measurements of isoprene, also showing two peaks, made for year 2002 at Tapajos National Forest in Brazil (Barkley et al., 2008, their Fig. 8).

The annual 3-D HCHO production ranges between $248 \mathrm{TgHCHO} \mathrm{yr}^{-1}$ (in 2005) and $276 \mathrm{TgHCHO} \mathrm{yr}^{-1}$ (in 2010), showing a slight interannual variability (IAV). Table 1 shows the regional variation of the 3-D HCHO production by NMVOC between 2005 and 2010: tropical regions (South American Temperate, South East Asia, Northern Africa and Indonesia) are the main contributors to this IAV.

\section{Theoritical uncertainty reduction}

The Bayesian prior and the posterior uncertainties $(1 \sigma)$ on the 3-D HCHO production by NMVOC are presented in Table 1 for year 2006. By reducing the uncertainty, the inversion also improves the quality of the 3-D HCHO production by NMVOC estimates (Table 1). The uncertainty reduction is maximal in the regions South American Temperate $(27 \%)$, USA ( $20 \%)$, South American Tropical, Northern Africa (14\%) and Indonesia (14\%). Significant reductions are also observed for other regions (e.g. $8 \%$ in Western Europe). There is no error reduction in the two boreal regions (North American Boreal and Eurasian Boreal) due to the lack of OMI data north of $65^{\circ} \mathrm{N}$.

\subsubsection{Prior and posterior HCHO production by methane}

As the formaldehyde production by methane via the reaction with $\mathrm{O}^{1} \mathrm{D}$ is very small ( $1 \%$ of the global total), we only focus on the HCHO production by methane via the oxidation by $\mathrm{OH}$. The global prior HCHO production by methane is

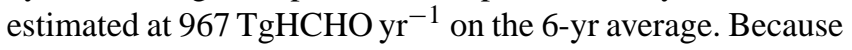
of the small uncertainties prescribed on prior MCF emissions and $\mathrm{MCF}$ observations constraining the $\mathrm{OH}$ concentrations (and consequently the loss of methane), the posterior $\mathrm{HCHO}$ production by methane is only $2 \%$ smaller than the corre-

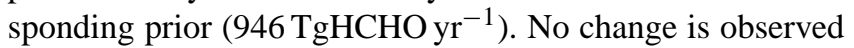
over the regions South American Temp, Middle East, Australia, Indonesia and the USA. The other regions see their $\mathrm{HCHO}$ production decrease only a few percentage points (i.e. $-3 \%$ for South East Asia) (not shown).

\subsubsection{Prior and posterior HCHO loss}

The global posterior $\mathrm{HCHO}$ loss is estimated at $1181{\mathrm{TgHCHO} \mathrm{yr}^{-1}}^{-1} 8 \%$ smaller than the corresponding prior of $1296 \mathrm{TgHCHO} \mathrm{yr}^{-1}$ on the 6 -yr average. As a consequence of the reduction of the NMVOC source, the main changes are seen only for regions that are impacted by the inversion in terms of HCHO production by NMVOC (Fig. 5): USA, South Asia and tropical regions. 


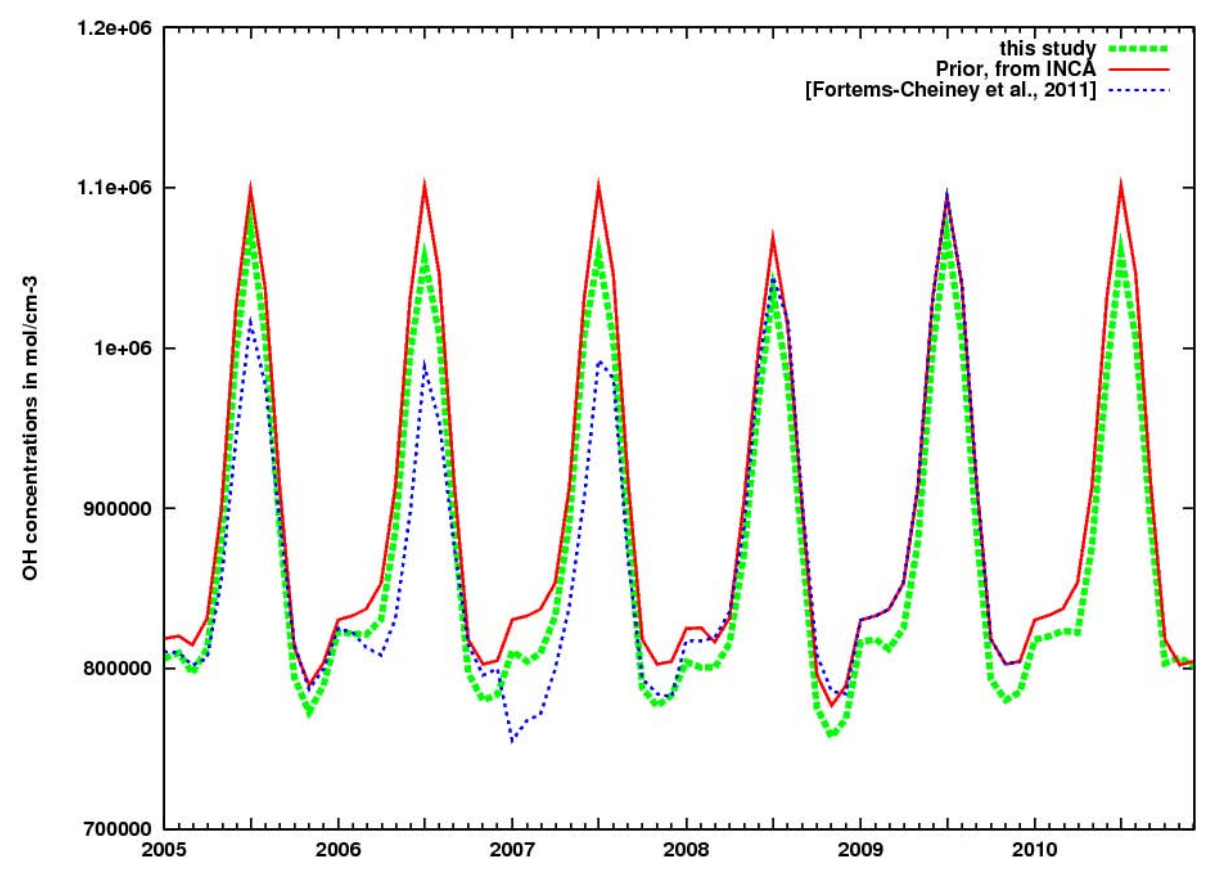

Fig. 7. Seasonal cycle of the global tropospheric mean of $\mathrm{OH}$ prior concentrations from LMDz-INCA (in red), $\mathrm{OH}$ posterior concentrations using only MOPITT as constraints from Fortems-Cheiney et al. (2011) (in blue) and OH posterior concentrations using OMI, MOPITT and surface stations (this study, in green), from January 2005 to December 2010 . Units are $\mathrm{mol} \mathrm{cm}^{-3}$.

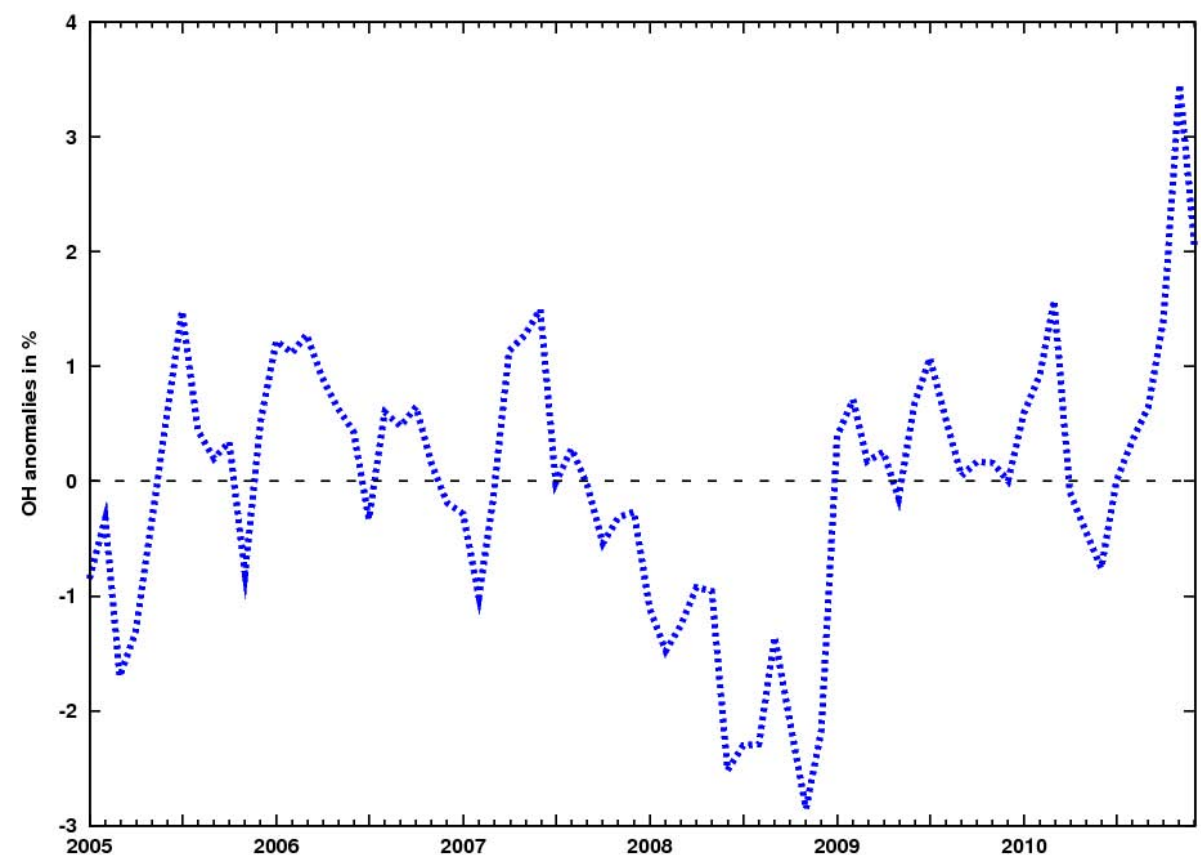

Fig. 8. Anomalies in global $\mathrm{OH}$ concentrations derived in our inversion from January 2005 to December 2010. Units are \%.

\subsection{Evaluation with independent data}

We evaluate the multi-constraint system's performance by comparing our posterior-modeled HCHO concentrations with independent observations. Considering that OMI data integrate the atmospheric column of $\mathrm{HCHO}$, comparison with aircraft observations are of particular interest. The airborne HCHO measurements made during INTEX-B (Intercontinental Chemical Transport Experiment B) (Singh et al., 2009; Fried et al., 2011) and AMMA (African Monsoon 
Table 2. Total CO emissions for years 2005 to 2010 before inversion and after inversion, for 14 continental regions and for the globe in

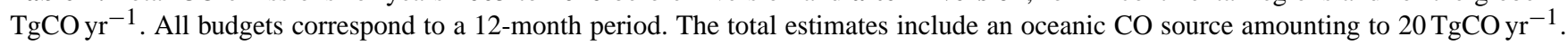
The uncertainty of the inverted fluxes for 2006 are computed by a Monte-Carlo approach.

\begin{tabular}{|c|c|c|c|c|c|c|c|c|c|c|c|c|}
\hline & \multicolumn{2}{|c|}{2005} & \multicolumn{2}{|c|}{2006} & \multicolumn{2}{|c|}{2007} & \multicolumn{2}{|c|}{2008} & \multicolumn{2}{|c|}{2009} & \multicolumn{2}{|c|}{2010} \\
\hline & prior & post & prior & post & prior & post & prior & post & prior & post & prior & post \\
\hline North Am Boreal & 11 & 59 & $9 \pm 13$ & $54 \pm 8$ & 7 & 52 & 7 & 47 & 7 & 44 & 7 & 52 \\
\hline USA & 116 & 147 & $117 \pm 19$ & $150 \pm 18$ & 119 & 149 & 117 & 145 & 117 & 146 & 117 & 150 \\
\hline South Am Trop & 36 & 24 & $34 \pm 12$ & $24 \pm 6$ & 38 & 28 & 36 & 25 & 36 & 27 & 36 & 43 \\
\hline South Am Temp & 116 & 186 & $66 \pm 23$ & $158 \pm 13$ & 121 & 208 & 60 & 143 & 60 & 128 & 60 & 194 \\
\hline Northern Africa & 154 & 97 & $141 \pm 23$ & $94 \pm 14$ & 161 & 112 & 144 & 104 & 144 & 97 & 144 & 121 \\
\hline Southern Africa & 107 & 142 & $92 \pm 21$ & $137 \pm 13$ & 96 & 134 & 104 & 140 & 104 & 122 & 104 & 159 \\
\hline Western Europe & 70 & 94 & $70 \pm 13$ & $92 \pm 7$ & 70 & 90 & 69 & 87 & 69 & 84 & 69 & 86 \\
\hline Eastern Europe & 40 & 68 & $41 \pm 15$ & $71 \pm 10$ & 39 & 65 & 40 & 61 & 40 & 60 & 40 & 65 \\
\hline Eurasian Boreal & 18 & 99 & $30 \pm 22$ & $110 \pm 16$ & 20 & 106 & 41 & 112 & 41 & 100 & 41 & 106 \\
\hline Middle East & 24 & 36 & $24 \pm 10$ & $34 \pm 7$ & 24 & 33 & 24 & 34 & 24 & 37 & 24 & 35 \\
\hline South Asia & 80 & 73 & $80 \pm 16$ & $66 \pm 11$ & 80 & 68 & 80 & 72 & 80 & 85 & 80 & 83 \\
\hline South East Asia & 168 & 208 & $168 \pm 20$ & $208 \pm 15$ & 201 & 242 & 164 & 193 & 164 & 210 & 164 & 208 \\
\hline Indonesia & 87 & 74 & $129 \pm 5$ & $122 \pm 4$ & 44 & 37 & 45 & 38 & 45 & 45 & 45 & 43 \\
\hline Australia & 18 & 81 & $29 \pm 14$ & $96 \pm 10$ & 25 & 91 & 18 & 81 & 18 & 99 & 18 & 82 \\
\hline Globe & 1066 & 1408 & $1047 \pm 68$ & $1434 \pm 66$ & 1065 & 1435 & 969 & 1303 & 969 & 1302 & 969 & 1445 \\
\hline
\end{tabular}

Multidisciplinary Analysis) (Reeves et al., 2010; Borbon et al., 2012) are used for this comparison. The INTEX-B data have been collected in March-May 2006 from aircrafts flying across Mexico and the Gulf Coast of the USA (4-22 March) and across the Pacific Ocean and the western coastal regions of the USA (17 April-15 May). We compute the ratio of the posterior to the prior bias between modeled and observed concentrations. Locations highlighted in green in Fig. 6, for which ratio is lower than 1 , show an improvement of the corresponding statistical indicator after optimization. Over Mexico, the mean bias is reduced by about $4 \%$ (from 2.6 to $2.5 \mathrm{ppb}$ ) after the inversion. However, as the prior and posterior simulated concentrations are both in a good agreement with the observations over the USA in March (Fig. 4), target period of the INTEX-B campaign, the ratios of the posterior to the prior bias only range from 0.88 to 1.01 over the Pacific Ocean and the western coastal regions of the USA (Fig. 6, top).

The airborne campaigns AMMA were carried out in August 2006, when the monsoon season was fully developed, across Niamey (Niger). With significant modifications in terms of magnitude (monthly mean value of about $1.5 \mathrm{TgHCHO}$ for the posterior, against about $3 \mathrm{TgHCHO}$ for the prior) and in terms of seasonal variations (with peaks both in the wet and dry season) over Northern Africa, the inversion leads to a dramatic improvement relative to the prior over the Niger, Benin, and Ghana (see Fig. 6, bottom), with a reduction of the mean bias (data minus model) by about $40 \%$ (from 3 to $1.8 \mathrm{ppb}$ ).

\subsection{Implications for the other species}

\subsubsection{OH concentrations}

Figure 7 compares the global tropospheric mean of $\mathrm{OH}$ concentration between the prior from the full chemistryclimate LMDz-INCA model (in red), the posterior derived from Fortems-Cheiney et al. (2011) (using the same inversion framework over the same period, but with only MOPITT-CO satellite data as constraints) and from this study for the period 2005-2010. From this study, the global OH posterior concentration value is $8.69 \times 10^{5} \mathrm{~mol} \mathrm{~cm}^{-3}$ on average, $17 \%$ smaller than the $10.5 \times 10^{5} \mathrm{~mol} \mathrm{~cm}^{-3}$ value of Prinn et al. (2005), and $1.6 \%$ higher than the $8.55 \times 10^{5} \mathrm{~mol} \mathrm{~cm}^{-3}$ of FortemsCheiney et al. (2011). Figure 8 shows the $\mathrm{OH}$ concentration anomalies over the period 2005-2010, relative to the mean. The interannual variability is less than $\pm 4 \%$, consistent with the low variations reported in Montzka et al. (2011) and compatible with the small IAV inferred by chemistry transport models (Dentener et al., 2003).

\subsubsection{CO surface emissions and atmospheric production}

The prior and posterior $\mathrm{CO}$ surface emissions are presented in Table 2 with their respective uncertainties $(1 \sigma)$ for year 2006. Posterior CO emissions and production from January 2005 to December 2010 reveal higher surface emissions (with contribution of all the regions except Northern Africa, South American Tropical, Indonesia and South Asia), and reduced atmospheric production than the prior estimates (Fig. 1b). The posterior emissions, with a global 6-yr average 
of $1394 \mathrm{TgCO} \mathrm{yr}^{-1}$, are $26 \%$ higher than the prior ones, built from the EDGAR-v3.2 and the GFED-v2 inventories $\left(1037 \mathrm{TgCO} \mathrm{yr}^{-1}\right.$ on average). These new global emission estimates for the years 2005-2010 are in a good agreement with the results of Fortems-Cheiney et al. (2011), being only $2 \%$ lower $\left(1429{\mathrm{TgCO} \mathrm{yr}^{-1}}^{-1}\right.$.

\section{Regional budget and comparison with recent studies}

Some regions show a very similar budget between MOPITT-OMI and MOPITT inversions: South Africa (142 and $149 \mathrm{TgCO} \mathrm{yr}^{-1}$ in 2005) and Australia (81 and $78 \mathrm{TgCO} \mathrm{yr}^{-1}$ in 2005). However, there are some differences on emissions (e.g. for the USA with $+11 \%$ ) due to the decrease of the CO tropospheric production over these regions. In our previous work with "MOPITT-only" inversion, we found $\mathrm{CO}$ emissions of $127 \mathrm{TgCO} \mathrm{yr}^{-1}$, much higher than Kopacz et al. (2010) results $\left(46.5 \mathrm{TgCO} \mathrm{yr}^{-1}\right)$. Here, the differences between our model and Kopacz et al. (2010) are increased as posterior emissions of $147.5 \mathrm{TgCO} \mathrm{yr}^{-1}$ are found. The cause of such a difference is still unclear. However, our value of $206 \mathrm{TgCO} \mathrm{yr}^{-1}$ for North America (6-yr average) is in agreement with Hooghiemstra et al. (2012) who found $208 \mathrm{TgCO} \mathrm{yr}^{-1}$ and $202 \mathrm{TgCO} \mathrm{yr}^{-1}$ (inverted respectively with NOAA stations and with MOPITT for year 2004, their Table 1).

On the contrary, we notice that the "MOPITT-OMI"based emissions are much smaller than the "MOPITT-only"based ones in the Middle East region ( $-50 \%$, from 75 to $36 \mathrm{TgCO} \mathrm{yr}^{-1}$ ) and may be more realistic given the relatively small size of the region and its emission profile. This surface emission decrease is compensated by an increase of the CO atmospheric source. Region South East Asia region also sees its emissions decrease (by $19 \%$, from 274 to $208 \mathrm{TgCO} \mathrm{yr}^{-1}$ ), reaching a better agreement with the optimized value of $207 \mathrm{TgCO} \mathrm{yr}^{-1}$ from Pétron et al. (2004) and of $169-228 \mathrm{TgCO} \mathrm{yr}^{-1}$ from Carmichael et. (2003). This modification is allowed by a better fit of the posterior simulated concentrations to the MOPITT observations (not shown).

\section{Interannual variability}

In terms of IAV, mostly explained by changes in biomass burning emissions and climate (Szopa et al., 2007; van der Werf et al., 2008, 2010), it should be noted that there is no noticeable change between this study and the work of Fortems-Cheiney et al. (2011). The lowest estimation of annual CO emissions is seen for years 2008 and 2009 with 1303 and $1302 \mathrm{TgCO} \mathrm{yr}^{-1}$, respectively. The highest emissions of the 2005-2010 period are seen for year 2010 (with $1445 \mathrm{TgCO} \mathrm{yr}^{-1}, 10 \%$ higher than the 2009 estimation.), followed by year 2007 (with $1435 \mathrm{TgCO} \mathrm{yr}^{-1}$ ) and year 2006 (with $1434 \mathrm{TgCO} \mathrm{yr}^{-1}$ ).
The annual budgets (Table 2) show that the $2006 \mathrm{CO}$ emissions are higher than in other years over Indonesia. This is linked to the 2006 El Niño-Southern Oscillation (ENSO) event, which was associated with drought and the greatest rise in wildfire activity in Indonesia since the recordbreaking 1997-1998 El Niño (Logan et al., 2008; Chandra et al., 2009).

From Table 2, it can be seen that only two regions are responsible of the high level of CO emissions in 2007: South East Asia and South American Temperate $(+44 \mathrm{TgCO}$ and $+50 \mathrm{TgCO}$, respectively, between 2006 and 2007). For South East Asia, it should be noted that the 2007 biomass burning emissions (particularly the peak in March) were extremely high, whereas the biomass burning emissions in the other years could be considered as normal (Fortems-Cheiney et al., 2011).

After low value in $2006\left(158 \mathrm{TgCO} \mathrm{yr}^{-1}\right)$ related to unfavorable climate conditions (Gloudemans et al., 2009; Schroeder et al., 2009), there was a peak in CO emissions in $2007\left(208 \mathrm{TgCO} \mathrm{yr}^{-1}\right)$ over the region South American Temperate, correlated with the largest number of fires detected from space over the last $10 \mathrm{yr}$ (Torres et al., 2010). In 2008 and 2009, the $\mathrm{CO}$ emissions show a negative trend with, respectively, $143 \mathrm{TgCO} \mathrm{yr}^{-1}$ and $128 \mathrm{TgCO} \mathrm{yr}^{-1}$. However, $\mathrm{CO}$ emissions returned to high levels in 2010. This increase is explained by the Amazon drought, co-occuring with peaks of fire activity (Lewis et al., 2011) and higher biomass burning emissions in the South American Temperate region (+66 TgCO between 2009 and 2010).

\section{Theoritical uncertainty reduction}

The prior and the posterior uncertainties $(1 \sigma)$ on the $\mathrm{CO}$ emissions are presented in Table 2 for year 2006. The uncertainty reduction is maximal for the South American regions (46\% and $43 \%$, respectively, for South American Tropical and South American Temperate), and for Western Europe $(43 \%)$.

\section{Evaluation with independant data and impact of the ad- ditional constraints}

The posterior "MOPITT-OMI" emissions are evaluated for year 2006 by comparing the prior and the posterior modeled $\mathrm{CO}$ concentrations with independent (i.e. not used in the inversion) and fixed surface measurements from various networks (NOAA/ESRL, AGAGE, CSIRO, EMPA, SAWS, NIWA and JMA/MRI) available on the WDCGG website. We have restricted our analysis to 39 sites (33 in the Northern Hemisphere presented in Table 3 and 6 at the high-latitudes of the Southern Hemisphere presented in Table 4) representing remote areas (i.e. Barrow, South Pole), or on the contrary, stations close to source regions (i.e. Jungfraujoch, Sonnblick, 
Table 3. Statistics of the fit for the 33 stations chosen in the Northern Hemisphere. Bias is defined as the mean difference between observed and modeled CO concentrations (model-minus-observation, average over the year 2006). The "MOPITT-only posterior" bias is given by Fortems-Cheiney et al. (2011). The lowest bias for each station is highlighted in bold.

\begin{tabular}{|c|c|c|c|c|}
\hline \multirow[b]{2}{*}{ Code } & \multirow[b]{2}{*}{ Location } & \multicolumn{3}{|c|}{ Biais [ppb] } \\
\hline & & Prior & Posterior & $\begin{array}{r}\text { MOPITT-only } \\
\text { posterior }\end{array}$ \\
\hline ALT & Alert, Canada & -25.8 & 17.0 & 13.1 \\
\hline ASC & Ascension Island, UK & -7.7 & -0.6 & -0.7 \\
\hline ASK & Assekrem, Algeria & -18.9 & -10.1 & -6.4 \\
\hline AZR & Terceira Island, Portugal & -29.8 & -9.2 & -7.7 \\
\hline BMW & Tudor Hill, IK & -12.5 & -11.7 & 12.5 \\
\hline BRW & Barrow, USA & -28.5 & 20.3 & $\mathbf{1 7 . 5}$ \\
\hline BSC & Black Sea, Romania & -38.7 & 4 & 3.6 \\
\hline CBA & Cold Bay, USA & -33.6 & 11.2 & 10.8 \\
\hline CHR & Christmas Island, Kiribati & -7.8 & -5.5 & -5.7 \\
\hline EIC & Easter Island, Chile & -9.0 & 2.1 & 1.3 \\
\hline GMI & Mariana Islands, Guam & -23.6 & -16.4 & -13.8 \\
\hline ICE & Heimay, Iceland & -23.7 & 10.4 & 7.6 \\
\hline IZO & Izana, Spain & -23.7 & -13.8 & -10.0 \\
\hline JFJ & Jungfraujoch, Switzerland & -24.9 & -0.4 & -23 \\
\hline KUM & Cape Kumukahi & -24.1 & -7.3 & -8.2 \\
\hline KZM & Plateau Assy, Kazakhstan & -22.5 & 11.4 & 17.8 \\
\hline MHD & Mace Head, Ireland & -25.0 & 3.3 & 4.3 \\
\hline MID & Sand Island, USA & -24.8 & -12.4 & -12.9 \\
\hline MLO & Mauna Loa, USA & -32.6 & -16.8 & -14.6 \\
\hline MNM & Minamitorishima, Japan & -15.1 & -2.4 & -6.1 \\
\hline NWR & Niwot Ridge, USA & -30.4 & -11.6 & -9.2 \\
\hline PAY & Payerne, Switzerland & -54.7 & -10.4 & -19.5 \\
\hline RIG & Rigi, Switzerland & -14.2 & 23.3 & 19.0 \\
\hline RPB & Ragged Point, Barbados & -15.9 & -8.7 & -5.5 \\
\hline RYO & Ryori, Japan & -44.1 & 11.7 & 20.5 \\
\hline SEY & Mahe Island, Seychelles & -5.2 & -6.3 & 3.2 \\
\hline SHM & Shemya Island, USA & -32.7 & 3.1 & 3.8 \\
\hline SNB & Sonnblick, Austria & -77.2 & 52.5 & -54.8 \\
\hline SMO & Cape Matatula, American Samoa & -6.6 & -0.8 & -0.2 \\
\hline UUM & Ulaan Uul, Mongolia & -29.1 & 25.2 & 27.2 \\
\hline WIS & Sede Boker, Israel & -22.9 & 4.2 & 22.5 \\
\hline WLG & Mt. Waliguan, China & -37.3 & -15.9 & 19.8 \\
\hline ZEP & Ny-Alesund, Spitsbergen & -22.9 & 25.2 & 22.5 \\
\hline ALL & & 25.6 & 11.6 & 12.8 \\
\hline
\end{tabular}

Table 4. Same as Table 3, but for the 6 stations chosen in the highlatitudes of the Southern Hemisphere.

\begin{tabular}{llrcr}
\hline & & \multicolumn{3}{c}{ Biais [ppb] } \\
\hline Code & Location & Prior & $\begin{array}{r}\text { MOPITT } \\
\text { posterior }\end{array}$ & $\begin{array}{r}\text { MOPITT-OMI } \\
\text { posterior }\end{array}$ \\
\hline CGO & Cape Grim, Australia & $\mathbf{1 2 . 5}$ & 42.2 & 37.8 \\
HBA & Halley Station, UK & $\mathbf{0 . 3}$ & 11.1 & 9.1 \\
PSA & Palmer Station, USA & $\mathbf{- 0 . 4}$ & 12.9 & 13.2 \\
SPO & South Pole, USA & $\mathbf{1 . 1}$ & 13.8 & 13.8 \\
SYO & Syowa Station, Japan & $\mathbf{2 . 9}$ & 17.2 & 18.0 \\
TDF & Tierra del Fuego, Argentina & $\mathbf{- 1 . 0}$ & 13.1 & 13.5 \\
\hline
\end{tabular}

Ryori). We have computed the posterior and the prior bias between the modeled and observed concentrations per station.

The inversion leads to a large improvement relative to the prior simulation for all the stations of Northern Hemisphere with an average reduction of the bias by about $60 \%$, except for the boreal station Ny-Alesund (increase of the bias by $10 \%$ ) due to the lack of satellites constraints in the highlatitudes. The largest improvement is seen for the station Sede Boker in Israel (WIS), where the inversion significantly decreases the emissions: the reduction of the bias reached about $80 \%$ compared to the prior and to the "MOPITTonly" simulation. However, as seen in Table 4 and as already pointed out by Arellano et al. (2004) and by Stavrakou and 
Table 5. Total $\mathrm{CH}_{4}$ emissions for years 2005 to 2010, before inversion and after inversion, for 14 continental regions and for the globe in $\mathrm{TgCH}_{4} \mathrm{yr}^{-1}$. All budgets correspond to a 12-month period.

\begin{tabular}{|c|c|c|c|c|c|c|c|c|c|c|c|c|}
\hline & \multicolumn{2}{|c|}{2005} & \multicolumn{2}{|c|}{2006} & \multicolumn{2}{|c|}{2007} & \multicolumn{2}{|c|}{2008} & \multicolumn{2}{|c|}{2009} & \multicolumn{2}{|c|}{2010} \\
\hline & prior & post & prior & post & prior & post & prior & post & prior & post & prior & post \\
\hline North Am Boreal & 17 & 18 & 17 & 22 & 17 & 20 & 17 & 20 & 17 & 21 & 17 & 19 \\
\hline USA & 50 & 61 & 50 & 62 & 50 & 62 & 50 & 63 & 50 & 62 & 50 & 64 \\
\hline South Am Trop & 19 & 20 & 19 & 20 & 19 & 20 & 19 & 20 & 19 & 20 & 19 & 19 \\
\hline South Am Temp & 53 & 55 & 50 & 45 & 54 & 66 & 50 & 52 & 50 & 53 & 50 & 49 \\
\hline Northern Africa & 36 & 40 & 36 & 39 & 37 & 42 & 36 & 41 & 36 & 40 & 36 & 38 \\
\hline Southern Africa & 18 & 19 & 17 & 17 & 18 & 19 & 18 & 19 & 18 & 19 & 18 & 19 \\
\hline Western Europe & 35 & 29 & 35 & 29 & 35 & 29 & 35 & 38 & 35 & 28 & 35 & 31 \\
\hline Eastern Europe & 31 & 28 & 31 & 29 & 31 & 31 & 31 & 31 & 31 & 30 & 31 & 30 \\
\hline Eurasian Boreal & 28 & 24 & 29 & 30 & 28 & 31 & 29 & 29 & 29 & 28 & 29 & 28 \\
\hline Middle East & 11 & 11 & 11 & 11 & 11 & 11 & 11 & 11 & 11 & 11 & 11 & 11 \\
\hline South Asia & 63 & 72 & 63 & 73 & 63 & 76 & 63 & 76 & 63 & 69 & 63 & 72 \\
\hline South East Asia & 84 & 95 & 84 & 95 & 86 & 95 & 84 & 90 & 84 & 91 & 84 & 96 \\
\hline Indonesia & 35 & 34 & 34 & 36 & 32 & 38 & 32 & 36 & 32 & 37 & 32 & 34 \\
\hline Australia & 11 & 10 & 11 & 10 & 11 & 10 & 11 & 9 & 11 & 9 & 11 & 11 \\
\hline Globe & 491 & 515 & 490 & 518 & 491 & 552 & 486 & 537 & 486 & 520 & 486 & 523 \\
\hline
\end{tabular}

Müller (2006), the fit is degraded at the high-latitude Southern Hemisphere sites.

The mean global "MOPITT-OMI" posterior bias is estimated at $11.6 \mathrm{ppb}, 10 \%$ smaller than the $12.8 \mathrm{ppb}$ mean "MOPITT-only" posterior bias, confirming that the synergistic use of different datasets is required to better quantify $\mathrm{CO}$ emissions, even if the improvement is not clearly noticeable for some stations.

\subsection{3 $\mathrm{CH}_{4}$ surface emissions}

\section{Budget}

The 6-yr average posterior $\mathrm{CH}_{4}$ emissions, from January 2005 to December 2010, presented in Table 5, are estimated at $529 \mathrm{TgCH}_{4} \mathrm{yr}^{-1}$, higher by $8 \%$ than the corresponding prior $\left(491 \mathrm{TgCH}_{4} \mathrm{yr}^{-1}\right)$. Our result is within the range of $500-600 \mathrm{TgCH}_{4}$ described in IPCC (2007). The main changes between prior and posterior emissions are seen over USA ( $+18 \%$, from 50 to $61 \mathrm{TgCH}_{4} \mathrm{yr}^{-1}$ in 2005) and over South Asia ( $+15 \%$, from 63 to $72 \mathrm{TgCH}_{4} \mathrm{yr}^{-1}$ in 2005). The inversion highlights the importance of the South East Asia region as a $\mathrm{CH}_{4}$ source with an average of $94 \mathrm{TgCH}_{4} \mathrm{yr}^{-1}$, followed by South Asia $\left(74 \mathrm{TgCH}_{4} \mathrm{yr}^{-1}\right)$ and South American Temperate $\left(53 \mathrm{TgCH}_{4} \mathrm{yr}^{-1}\right)$ regions.

\section{Interannual variability}

Global $\mathrm{CH}_{4}$ emissions show significant IAV, with total flux estimates ranging from $515 \mathrm{TgCH}_{4}$ (in 2005) to $552 \mathrm{TgCH}_{4}$ (in 2007) (see Table 5). It could be noted that the 2008 global emissions are also high, with a total of $537 \mathrm{TgCH}_{4} \mathrm{yr}^{-1}$.
The annual global budgets for 2009 and 2010 are estimated at, respectively, $520 \mathrm{TgCH}_{4} \mathrm{yr}^{-1}$ and $523 \mathrm{TgCH}_{4} \mathrm{yr}^{-1}$. The largest contributors to the global IAV of $\mathrm{CH}_{4}$ emissions are the tropical regions (South American Temperate, Northern Africa, South Asia, South East Asia and Indonesia). South American regions explain most of the observed atmospheric increase in 2007-2008.

Several studies attributed the IAV mostly to natural wetlands (Dlugokencky et al., 2009; Bousquet et al., 2011). Figure 9 shows the variation of the $\mathrm{CH}_{4}$ posterior emissions and the $\mathrm{CO}$ posterior emissions, used as a proxy for biomass burning, over the temperate region South America. This reveals that part of $\mathrm{CH}_{4}$ flux IAV in this region can be related to biomass burning emissions, at least in 2007. A peak of $\mathrm{CH}_{4}$ emissions appears to be correlated with a peak of $\mathrm{CO}$ emissions in September 2007, and to a lesser extent in September 2005, 2006 and 2008. It should be noted that 2007 was the year of the largest number of fires detected from space over the 2000-2009 period (Torres et al., 2010).

The mid-latitude and high-latitude $\mathrm{CH}_{4}$ emissions (for the regions USA, South American Tropical, Southern Africa, Middle East, Western and Eastern Europe, North American Boreal) seem to vary little from one year to the next (Table 5). However, the Eurasian Boreal annual budgets show that the $2007 \mathrm{CH}_{4}$ emissions are higher than in other years (31 $\mathrm{TgCH}_{4} \mathrm{yr}^{-1}$, compared with 28 to $30 \mathrm{TgCH}_{4} \mathrm{yr}^{-1}$ for years 2005, 2006, 2008, 2009 and 2010). This can be related to higher temperatures complemented by changes in continental precipitations impacting both methane flux densities and wetland extent in 2007 (Dlugokencky et al., 2009; Bousquet et al., 2011). 


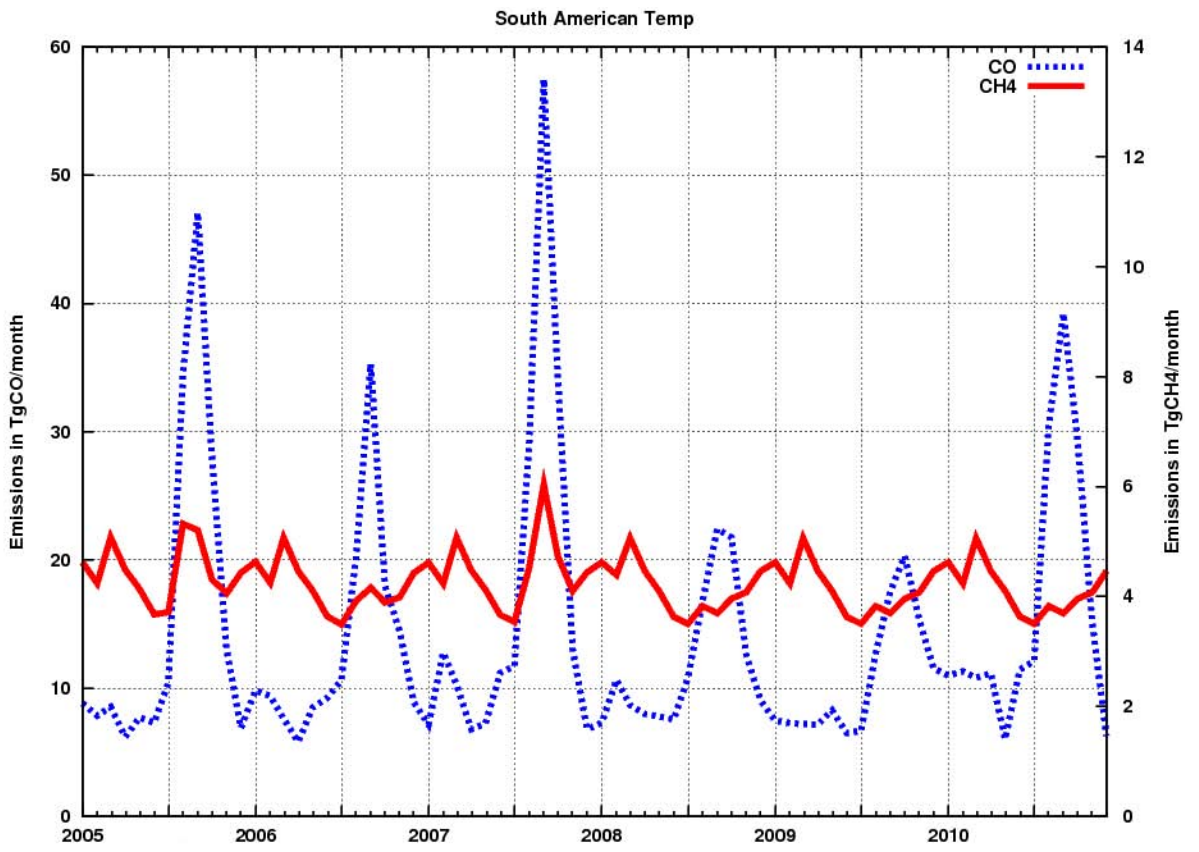

Fig. 9. Seasonal cycles of the posterior $\mathrm{CO}$ and $\mathrm{CH}_{4}$ emissions for the tropical region South American Temperate, respectively in $\mathrm{TgCO} /$ month and $\mathrm{TgCH}_{4} /$ month, from January 2005 to December 2010.

Table 6. Details of the sensitivity studies described in Sect. 6. The changes between the different sensitivity tests are highlighted in bold.

\begin{tabular}{lllll}
\hline & OH & $\begin{array}{l}\text { HCHO production by } \\
\text { NMVOC prior error }\end{array}$ & $\begin{array}{l}\text { CO emissions } \\
\text { prior error }\end{array}$ & $\begin{array}{l}\text { MCF emissions } \\
\text { prior error }\end{array}$ \\
\hline reference & OH-v1 & $400 \%$ & $100 \%$ & $1 \%$ \\
A & OH-v2 & $400 \%$ & $100 \%$ & $1 \%$ \\
B & OH-v1 & $\mathbf{2 0 0 \%}$ & $100 \%$ & $1 \%$ \\
C & OH-v1 & $400 \%$ & $\mathbf{1 5 0 \%}$ & $1 \%$ \\
D & OH-v1 & $400 \%$ & $100 \%$ & $\mathbf{1 0 \%}$ \\
\hline
\end{tabular}

\section{Sensitivity studies}

In this section, we discuss the robustness of our system from the spread of the regional $\mathrm{HCHO}$ production by NMVOC and of the regional $\mathrm{CO}$ and $\mathrm{CH}_{4}$ emissions in four sensitivity tests (cases A to D, described in Table 6) with respect to prior settings:

1. In case $\mathrm{A}$, the $\mathrm{OH}$ field is replaced by $\mathrm{OH}-\mathrm{v} 2$ field. The alternative field has also been derived from a simulation of the full chemistry model LMDz-INCA, but using another realistic emission scenario (the combination of anthropogenic emissions from IIASA, QUANTIFY for ship and GFEDv2 for biomass burning). OH-v2 field is within $5 \%$ of the reference $\mathrm{OH}$ field. All other settings are the same as in the reference.

2. In case $\mathrm{B}, \mathrm{HCHO}$ prior 3-D production by NMVOC error is set to $200 \%$ instead of $400 \%$.
3. In case $\mathrm{C}, \mathrm{CO}$ prior emissions error is set to $150 \%$ instead of $100 \%$.

4. In case $\mathrm{D}, \mathrm{MCF}$ prior emissions error is set to $10 \%$ instead of $1 \%$.

The $\mathrm{HCHO}$ production by NMVOC and $\mathrm{CO}$ and $\mathrm{CH}_{4}$ emissions for the whole year 2006, found from each test, are given for the 14 regions in Figs. 10a, 11a and 12a, respectively. These posterior regional results are further compared with the reference inversion in terms of anomalies in Figs. 10b, 11b and in Fig. 12b. For the three fields (HCHO production, $\mathrm{CO}$ and $\mathrm{CH}_{4}$ emissions). All sensitivity tests present the same departure from the prior as the reference inversion. The different sensitivity tests show very robust regional and global budgets.

For $\mathrm{CH}_{4}$ (Fig. 12a), the differences in yearly methane emission remain below $2 \%$ at the global scale and range between less than $1 \%$ (Middle East, Southern Africa) to $12 \%$ (Indonesia). 

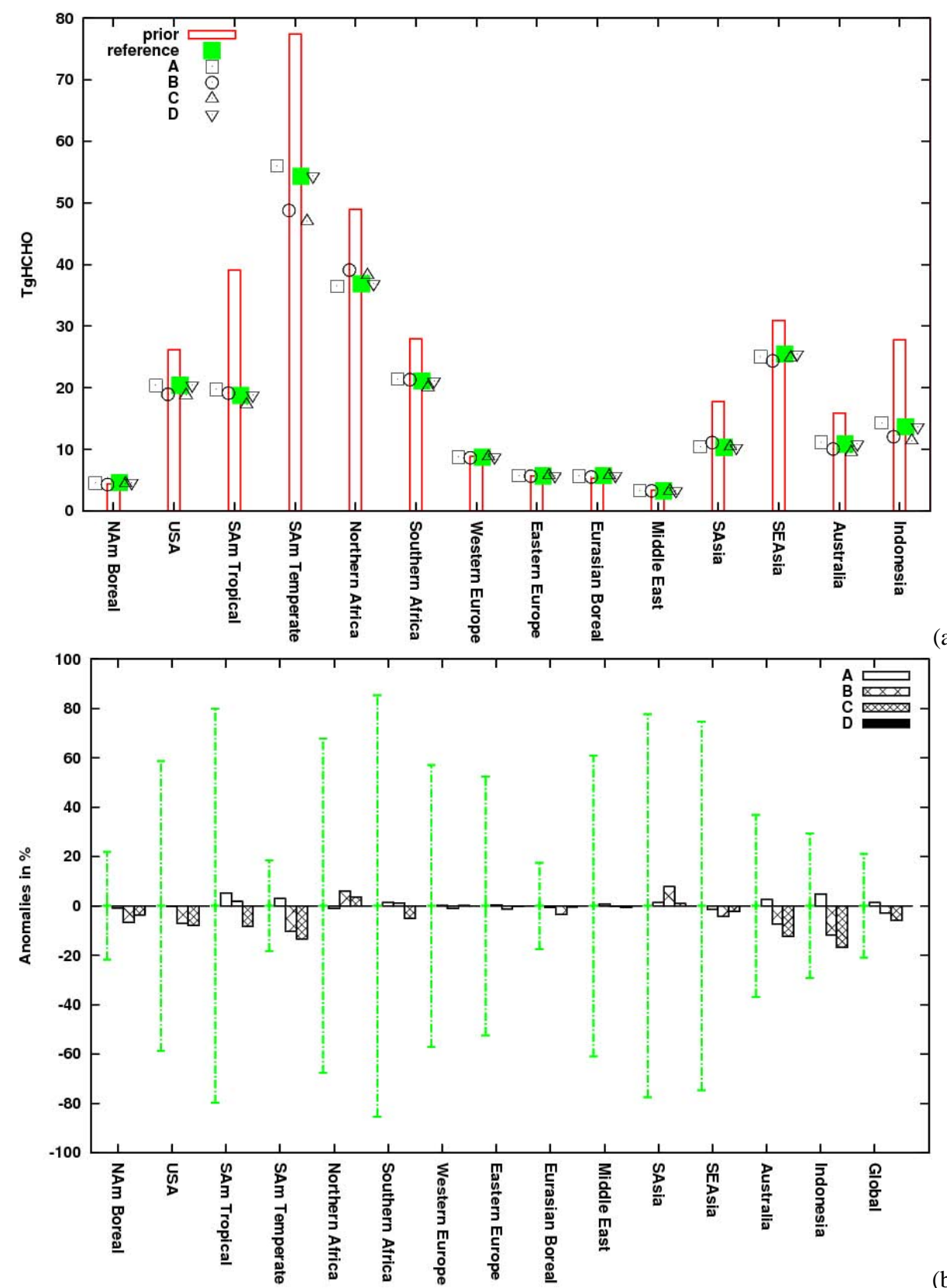

(a)

(b)

Fig. 10. (a) Regional 3-D HCHO production by NMVOC calculated for year 2006. The red bar represents the prior production and each symbol a posterior production, for the reference inversion (in green) and the four sensitivity cases (in black). Case A: OH-v2 field; Case B: error on the HCHO 3-D production set to $200 \%$; Case C: error on the prior CO emissions set to $150 \%$; Case D: error on the prior MCF emissions set to $10 \%$. (b) Differences of the posterior HCHO production between the sensitivity tests and the reference inversion (in $\%$ relative to the reference). Error bars show the $1-\sigma$ uncertainty associated with the posterior reference (calculated using the Monte-Carlo approach, see Sect. 4 for details).

The regional estimates of 3-D HCHO production by NMVOC estimates obtained by the different sensitivity tests are also in a strong agreement. The largest range is observed over the regions Indonesia and South American Temperate (17\% and $15 \%$, respectively) because of the smaller increments (compared to the reference) of cases B and C. Nev- ertheless, these regional results are largely within the error bounds of the reference inversion (calculated with a robust Monte-Carlo approach, see Sect. 4).

The largest scatterings between the sensitivity tests are seen for CO emissions at the regional scale. While on the global scale, the sensitivity tests show results within $2 \%$ of 

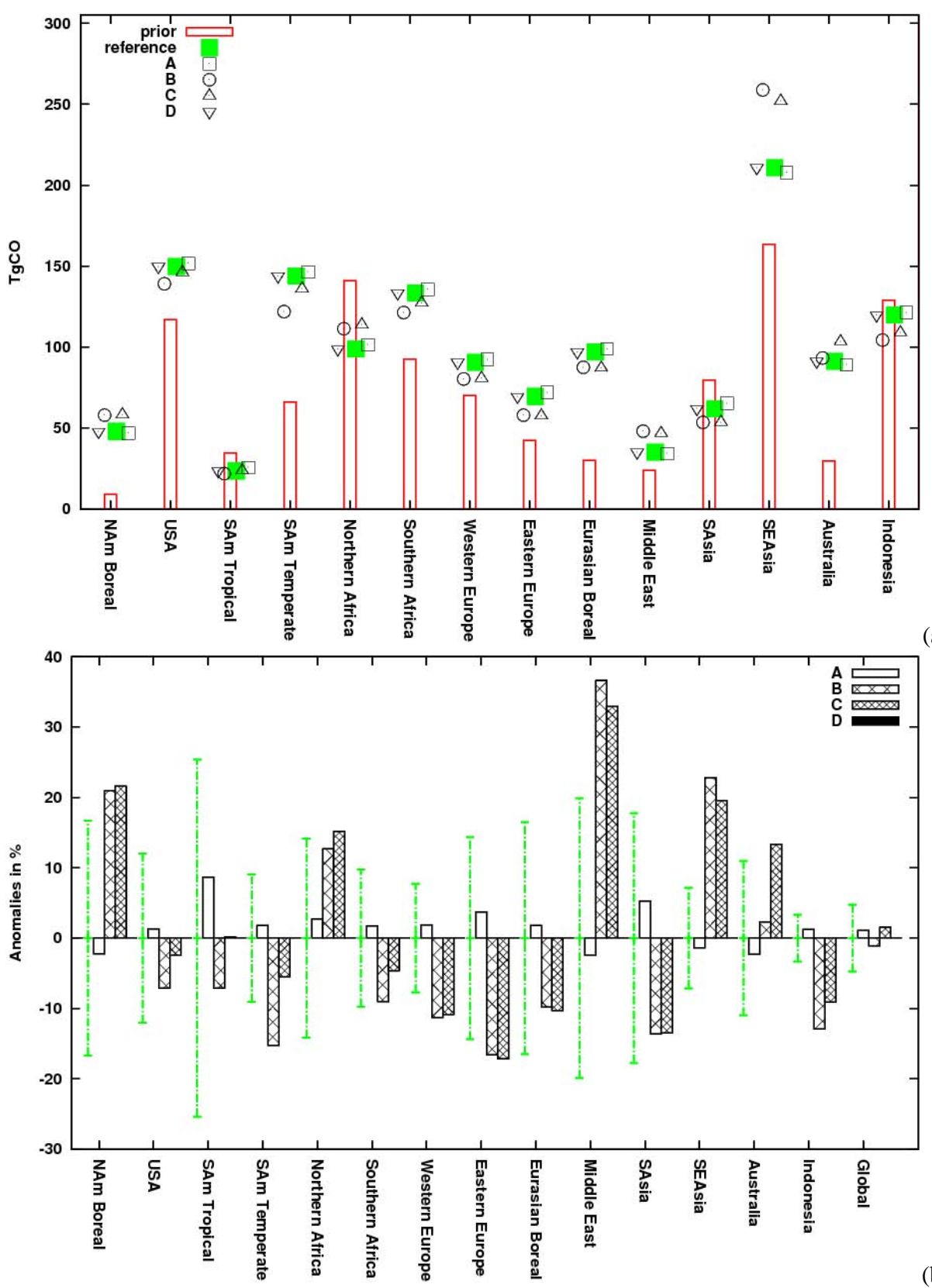

(a)

(b)

Fig. 11. Same as Fig. 10, but for CO emissions.

the reference inversion, the differences reach up to $39 \%$ at the regional scale. However, they are limited to $15 \%$ in all regions emitting about or more than $100 \mathrm{TgCO} \mathrm{yr}^{-1}$ (e.g. range of $14 \mathrm{TgCO}$ over Southern Africa, for an annual reference budget of $133 \mathrm{TgCO}$ ), except for South East Asia (range of $51 \mathrm{TgCO}$ for an annual reference budget of $208 \mathrm{TgCO}$ ).

The range of the inverted fluxes is well within the $1 \sigma$ posterior uncertainty for all regions, except for the regions Middle East, South East Asia and Indonesia. Finally, it is worthnoting that the difference between the regional inverted emissions in cases $\mathrm{B}, \mathrm{C}$ and $\mathrm{D}$ relative to the reference inversion is small, indicating that the inversion is not very sensitive to the prior errors statistics at the scales of interest here.

\section{Conclusions}

For the first time, an inversion of 3-D HCHO atmospheric production by NMVOC, carbon monoxide and methane emissions, together with $\mathrm{OH}$ concentrations, has been performed using a multi-constraint inversion system (using OMI and MOPITT satellite data, surface $\mathrm{CH}_{4}$ and MCF measurements as constraints). By comparing our posterior-modeled 

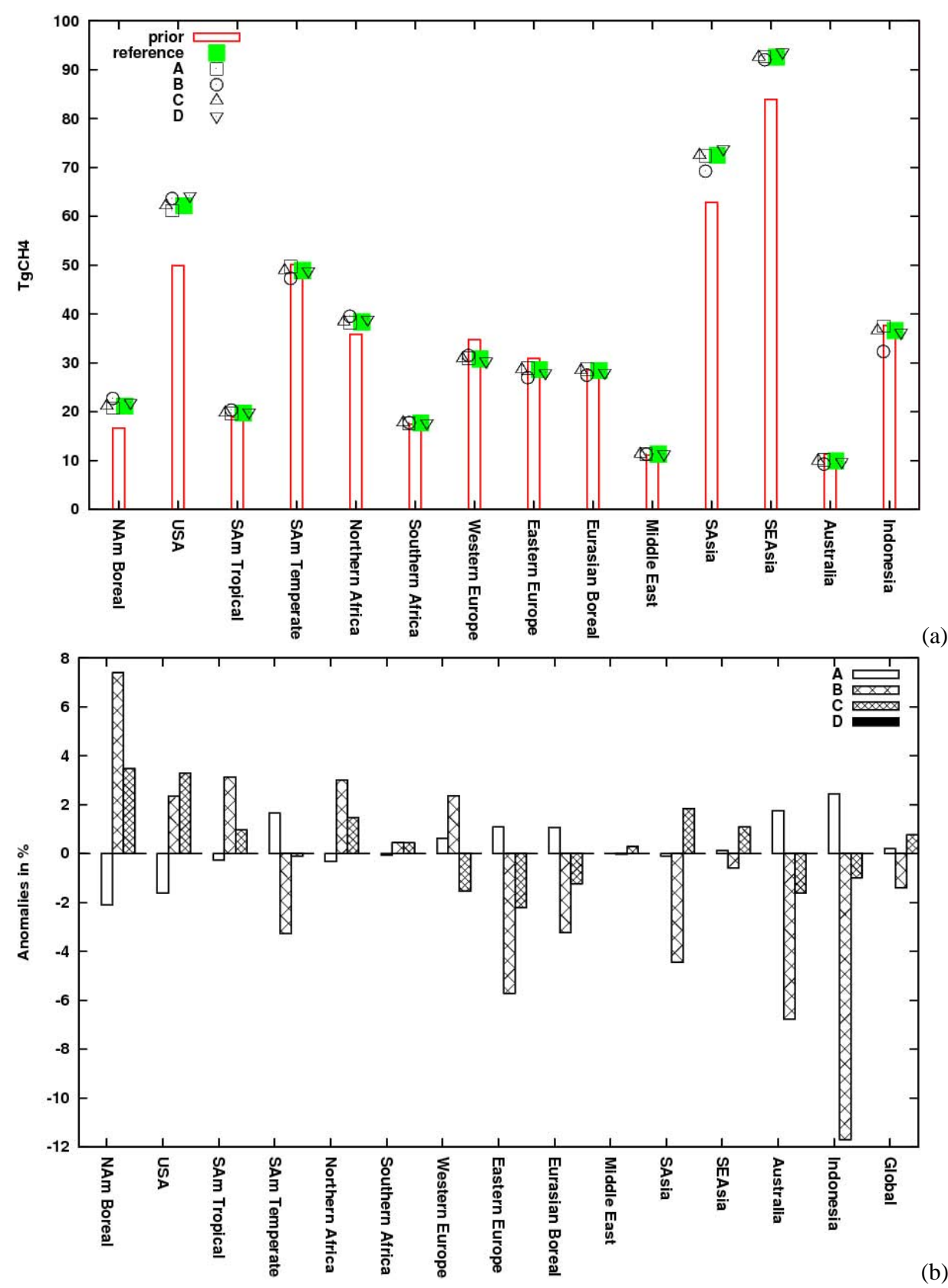

Fig. 12. Same as Fig. 10, but for $\mathrm{CH}_{4}$ emissions.

concentrations with independent surface and aircraft measurements, and by computing sensitivity tests, we have demonstrated the robustness of our multi-species inversion system to assimilate a large number of data from different types (satellites, surface) over the period 2005-2010. We infer robust $\mathrm{CO}$ and $\mathrm{CH}_{4}$ emission and $\mathrm{HCHO}$ production by NMVOC estimates. Such a robustness has been obtained despite the additional complexity implied by the connection of three tracers and of $\mathrm{OH}$ within a single inversion system. Nevertheless, even though our approach allows to widely spread adequate information between the tracers, it may probably spread biases as well.

Significant adjustments in the sources and sinks of formaldehyde are suggested in our study. The large reduction of HCHO concentrations, suggesting a large overestimation of the NMVOC emissions in the GEIA inventory, leads to a better agreement with the independent INTEX-B and AMMA data. The global posterior 3-D HCHO production by NMVOC of $257 \mathrm{TgHCHO}$ is about $28 \%$ smaller than the prior estimate of $358 \mathrm{TgHCHO}$. 
The inversion leads to few changes in the $\mathrm{OH}$ concentrations from prior to posterior, and suggests a small interannual variability. The global mean posterior $\mathrm{CH}_{4}$ emission flux of $529 \mathrm{TgCH}_{4} \mathrm{yr}^{-1}$ is $8 \%$ higher than the $490 \mathrm{TgCH}_{4} \mathrm{yr}^{-1}$ of the prior (on a 6-yr average). $\mathrm{CH}_{4}$ emissions have some significant interannual variability. The joint $\mathrm{CO}-\mathrm{CH}_{4}$ flux analysis suggests that tropical biomass burning probably played a role in the recent variations of atmospheric methane in South America. The highest annual budget over the period 20052010 is calculated in 2007 with $552 \mathrm{TgCH}_{4} \mathrm{yr}^{-1}$.

Our inverted global $\mathrm{CO}$ surface emission estimate is $1394 \mathrm{TgCO} \mathrm{yr}^{-1}, 26 \%$ higher than the corresponding prior but only $2 \%$ smaller than the estimate of Fortems-Cheiney et al. (2011) who inverted CO emissions from MOPITT only as constraints. Significant regional changes appeared between the two studies, particularly for Middle East and South East Asia, improving the agreement between the posterior concentrations and independent $\mathrm{CO}$ surface data in comparison to the single use of MOPITT. This highlights how promising the synergistic use of MOPITT, OMI and surface measurements for $\mathrm{CH}_{4}$ and MCF is to avoid aliasing between atmospheric chemistry (production and loss) signals and the fluxes at the surface and then to adjust the bottom-up inventories.

Our study relies on the quality of the HCHO column retrievals. While OMI provides a daily coverage dataset at high spatial resolution, uncertainties remain large for OMI data, and the scarcity of in situ measurements remains an issue for evaluation and validation. More efforts should be devoted to the implementation of a common database with uncertainties or a global measurement network for $\mathrm{HCHO}$ - as it exists for greenhouse gases or other air pollutants such as $\mathrm{CO}$ - spanning from urban to remote areas and from tropical to boreal regions.

Acknowledgements. This study was co-funded by the European Commission under the EU Seventh Research Framework Programme (grant agreement No. 283576, MACC II). We acknowledge the KNMI OMI, the NCAR MOPITT, and the NOAA ESRL, Global Monitoring Division (GMD), Halocarbons \& other Atmospheric Trace Species (HATS) and Carbon Cycle Greenhouse Gases (CCGG) groups for providing $\mathrm{HCHO}, \mathrm{CO}, \mathrm{MCF}$ and $\mathrm{CH}_{4}$ measurements. We contacted all data PIs and in particular thank H. J. R. Wang (AGAGE), J. W. Elkins (NOAA), K. Masarie (NOAA), S. A. Montzka (NOAA), P. C. Novelli (NOAA), E. Dlugokencky (NOAA), P. Krummel (CSIRO), R. Langenfeld (CSIRO), P. Steele (CSIRO), D. Worthy (EC), R. Moss (NIWA), M. Ramonet (LSCE), and G. Brailsford (NIWA). This work was performed using HPC resources of DSM-CCRT and of (CCRT/CINES/IDRIS) under the allocation 2011-t2011012201 made by GENCI (Grand Equipement National de Calcul Intensif). Research at the Smithsonian Astrophysical Observatory was supported by NASA. Finally, we wish to thank F. Marabelle and his team for computer support at LSCE.

Edited by: B. N. Duncan

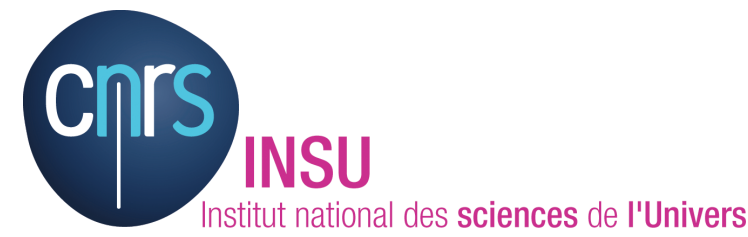

The publication of this article is financed by CNRS-INSU.

\section{References}

Abbot, D. S., Palmer, P. I., Martin, R. V., Chance, K. V., Jacob, D. J., and Guenther, A.: Seasonal and interannual variability of North American isoprene emissions as determined by formaldehyde columns measurements from space, Geophys. Res. Lett., 30, 1886, doi:10.1029/2003GL017336, 2003.

Arellano, A., Kasibhatla, P., Giglio, L., Van der Werf, G., and Randerson, J.: Top-down estimates of global CO using MOPITT measurements, Geophys. Res. Lett., 31, L01104, doi:10.1029/2003GL018609, 2004.

Barkley, M. P., Palmer, P. I., Kunh, U., Kesselmeier, J., Chance, K., Kurosu, T. P., Martin, R. V., Helmig, D., and Guenther, A.: Net ecosystem fluxes of isoprene over South America inferred from Global Ozone Monitoring Experiment (GOME) observations of HCHO columns, Geophys. Res., 113, D20301, doi:10.1029/2008JD009863, 2008.

Bergamaschi, P., Frankenberg, C., Meirink, J. F., Krol, M., Villani, M. G., Houweling, S., Den- tener, F., Dlugokencky, E. J., Miller, J. B., Gatti, L. V., Engel, A., and Levin, I.: Inverse modeling of global and regional $\mathrm{CH}_{4}$ emissions using SCIAMACHY satellite retrievals, J. Geophys. Res., 114, D22301, doi:10.1029/2009JD012287, 2009.

Boeke, N. L., Marshall, J. D., Alvarez, S., Chance, K. V., Fried, A., Kurosu, T. P., Rappengluck, B., Richter, D., Walega, J., Weibring, P., and Millet, D. B.: Formaldehyde columns from the Ozone Monitoring Instrument: Urban versus background levels and evaluation using aircraft data and a global model, J. Geophys. Res., 116, D05303, doi:10.1029/2010JD014870, 2011.

Borbon, A., Ruiz, M., Bechara, J., Aumont, B., Chong, M., Huntrieser, H., Mari, C., Reeves, C. E., Scialom, G., Hamburger, T., Stark, H., Afif, C., Jambert, C., Mills, G., Schlager, H., and Perros, P. E.: Transport and chemistry of formaldehyde by mesoscale convective systems in West Africa during AMMA 2006, J. Geophys. Res., 117, D12301, doi:10.1029/2011JD017121, 2012.

Bousquet, P., Hauglustaine, D. A., Peylin, P., Carouge, C., and Ciais, P.: Two decades of $\mathrm{OH}$ variability as inferred by an inversion of atmospheric transport and chemistry of methyl chloroform, Atmos. Chem. Phys., 5, 2635-2656, doi:10.5194/acp-52635-2005, 2005.

Bousquet, P., Ciais, P., Miller, J., Dlugokencky, B., Hauglustaine, D. A., Prigent, C., van der Werf, G. R., Peylin, P., Brunke, E.-G., Carouge, C., Langenfeld, R. L., Lathiere, J., Papa, F., Ramonet, M., Schmidt, M., Steele, L. P., Tyler, S. C., and White, J.: Contribution of anthropogenic and natural sources to atmospheric methane variability, Nature, 443, 439443, doi:10.1038/nature05132, 2006.

Bousquet, P., Ringeval, B., Pison, I., Dlugokencky, E. J., Brunke, E.-G., Carouge, C., Chevallier, F., Fortems-Cheiney, A., 
Frankenberg, C., Hauglustaine, D. A., Krummel, P. B., Langenfelds, R. L., Ramonet, M., Schmidt, M., Steele, L. P., Szopa, S., Yver, C., Viovy, N., and Ciais, P.: Source attribution of the changes in atmospheric methane for 2006-2008, Atmos. Chem. Phys., 11, 3689-3700, doi:10.5194/acp-11-3689-2011, 2011.

Butler, T. M., Rayner, P. J., Simmonds, I., and Lawrence, M. G.: Simultaneous mass balance inverse modeling of methane and carbon monoxide, J. Geophys. Res., 110, D21, D21310, doi:10.1029/2005JD006071, 2005.

Carmichael, G., Tang, Y., Kurata, G., Uno, I., and Streets, D.: Evaluating regional emissions estimates using the TRACE-P observations, J.Geophys. Res., 108, 8810, doi:10.1029/2002JD003116, 2003.

Chandra, S., Ziemke, J. R., Duncan, B. N., Diehl, T. L., Livesey, N. J., and Froidevaux, L.: Effects of the 2006 El Niño on tropospheric ozone and carbon monoxide: implications for dynamics and biomass burning, Atmos. Chem. Phys., 9, 4239-4249, doi:10.5194/acp-9-4239-2009, 2009.

Chevallier, F., Fisher, M., Peylin, P., Serrar, S., Bousquet, P., Breon, F.-M., Chedin, A., and Ciais, P.: Inferring $\mathrm{CO}_{2}$ sources and sinks from satellite observations: method and application to TOVS data, J. Geophys. Res., 110, D24309, doi:10.1029/2005JD006390, 2005.

Chevallier, F., Breon, F.-M., and Rayner, P.: The contribution of the Orbiting Carbon Observatory to the estimation of $\mathrm{CO}_{2}$ sources and sinks: Theoretical study in a variational data assimilation framework, J. Geophys. Res., 112, D09307, doi:10.1029/2006JD007375, 2007.

Chevallier, F., Fortems, A., Bousquet, P., Pison, I., Szopa, S., Devaux, M., and Hauglustaine, D. A.: African CO emissions between years 2000 and 2006 as estimated from MOPITT observations, Biogeosciences, 6, 103-111, doi:10.5194/bg-6-103-2009, 2009.

Crawford, J., Heald, C., Fuelberg, H., Morse, D., Sachse, G., Emmons, L., Gille, J., Edward, D., Deeter, M., Chen, G., Olson, J., Connors, V., Kittaka, C., and Hamlin, A.: Relationship between measurements of MOPITT and in-situ observations of CO based on a large-scale feature sampled during TRACE-P, J. Geophys. Res., 109, D15S04, doi:10.1029/2002JD004308, 2004.

De Smedt, I., Müller, J.-F., Stavrakou, T., van der A, R., Eskes, H., and Van Roozendael, M.: Twelve years of global observations of formaldehyde in the troposphere using GOME and SCIAMACHY sensors, Atmos. Chem. Phys., 8, 4947-4963, doi:10.5194/acp-8-4947-2008, 2008.

Deeter, M., Edwards, D., Gille, J., Emmons, L., Francis, G., Ho, S.-P., Mao, D., Masters, D., Worden, H., Drummond, J., and Novelli, P.: The MOPITT Version 4 CO Product: Algorithm Enhancements, Validation, and Long-Term Stability, J. Geophys. Res., 115, D07306, doi:10.1029/2009JD013005, 2010.

Dentener, F., Peters, W., Krol, M., van Weele, M., Bergamaschi, P., and Lelieveld, J.: Interannual variability and trend of $\mathrm{CH}_{4}$ lifetime as a measure for $\mathrm{OH}$ changes in the 1979-1993 time period, J. Geophys. Res.-Atmos., 108, 4442, doi:10.1029/2002JD002916, 2003.

Dlugokencky, E. J., Bruhwiler, L., White, J. W. C, Emmons, L. K., Novelli, P. C., Montzka, S. A., Masarie, K. A., Lang, P. M., Crotwell, A. M., Miller, J. B., and Gatti, L. V.: Observational constraints on recent increases in the atmospheric $\mathrm{CH}$ burden, Geophys. Res. Lett, 36, L18803, doi:10.1029/2009GL039780, 2009.
Drummond, J., Zou, J., Nichitiu, F., Kar, J., Deschambaut, R., and Hackett, J.: A review of 9-year performance and operation of the MOPITT instrument, Adv. Space Res., 45, 760-774, doi:10.1016/j.asr.2009.11.019, 2009.

Ehhalt, D. and Prather, M.: Atmospheric Chemistry and Greenhouses Gases, in: Climate Change 2011: The Scientific Basis, edited by: Houghton, J. T., Ding, Y., Driggsn, D. J., Noguer, M., van der Linden, P. J., Dai, X., Maskell, K., and Johnson, C. A., Cambridge Univ. Press, New York, NY, 2001.

Emmons, L., Deeter, M., Gille, J., Edwards, D., and Attie, J.L.: Validation of measurements of MOPITT CO retrievals with aircraft in situ profiles, J. Geophys. Res., 108, D03309, doi:10.1029/2003JD004101, 2004.

Emmons, L., Pfister, G., Edwards, D., Gille, J., Sachse, G., Blake, D., Wofsy, S., Gerbig, C., ans Matross, D., and Nedelec, P.: MOPITT validation exercises during summer 2004 field campaigns over North America, J. Geophys. Res., 112, D12S02, doi:10.1029/2006JD007833, 2007.

Emmons, L. K., Edwards, D. P., Deeter, M. N., Gille, J. C., Campos, T., Nédélec, P., Novelli, P., and Sachse, G.: Measurements of Pollution In The Troposphere (MOPITT) validation through 2006, Atmos. Chem. Phys., 9, 1795-1803, doi:10.5194/acp-91795-2009, 2009.

Folberth, G. A., Hauglustaine, D. A., Lathière, J., and Brocheton, F.: Interactive chemistry in the Laboratoire de Météorologie Dynamique general circulation model: model description and impact analysis of biogenic hydrocarbons on tropospheric chemistry, Atmos. Chem. Phys., 6, 2273-2319, doi:10.5194/acp-62273-2006, 2006.

Fortems-Cheiney, A., Chevallier, F., Pison, I., Bousquet, P., Szopa, S., Deeter, M. N., and Clerbaux, C.: Ten years of $\mathrm{CO}$ emissions as seen from Measurements of Pollution in the Troposphere (MOPITT), J. Geophys. Res., 116, D05304, doi:10.1029/2010JD014416, 2011.

Fried, A., Cantrell, C., Olson, J., Crawford, J. H., Weibring, P., Walega, J., Richter, D., Junkermann, W., Volkamer, R., Sinreich, R., Heikes, B. G., O’Sullivan, D., Blake, D. R., Blake, N., Meinardi, S., Apel, E., Weinheimer, A., Knapp, D., Perring, A., Cohen, R. C., Fuelberg, H., Shetter, R. E., Hall, S. R., Ullmann, K., Brune, W. H., Mao, J., Ren, X., Huey, L. G., Singh, H. B., Hair, J. W., Riemer, D., Diskin, G., and Sachse, G.: Detailed comparisons of airborne formaldehyde measurements with box models during the 2006 INTEX-B and MILAGRO campaigns: potential evidence for significant impacts of unmeasured and multigeneration volatile organic carbon compounds, Atmos. Chem. Phys., 11, 11867-11894, doi:10.5194/acp-11-11867-2011, 2011.

Fu, T.-M., Jacob, D. J., Palmer, P. I., Chance, K., Wang, Y. X., Barletta, B., Blake, D. R., Stanton, J. C., and Pilling, M. J.: Space-based formaldehyde measurements as constraints on volatile organic compound emissions in east and south Asia and implications for ozone, J. Geophys. Res., 112, D06312, doi:10.1029/2006JD007853, 2007.

Fung, I., John, J., Lerner, J., Matthew, E., Prather, M., Steele, P., and Fraser, P.: 3-Dimensional model synthesis of the global methane cycle, J. Geophys. Res., 96, 13033-13065, doi:10.1029/91JD01247, 1991.

Gilbert, J. and Lemaréchal, C.: Some numerical experiments with variable-storage quasi-Newton algorithms, Math. Programm, 45, 407-435, 1989. 
Gloudemans, A. M. S., de Laat, A. T. J., Schrijver, H., Aben, I., Meirink, J. F., and van der Werf, G. R.: SCIAMACHY CO over land and oceans: 2003-2007 interannual variability, Atmos. Chem. Phys., 9, 3799-3813, doi:10.5194/acp-9-3799-2009, 2009.

Guenther, A., Hewitt, C. N., Erickson, D., Fall, R., Geron, C., Graedel, T., Harley, P., Klinger, L., Lerdau, M., McKay, W. A., Pierce, T., Scholes, B., Steinbrecher, R., Tallamraju, R., Taylor, J., and Zimmerman, P.: A global model of natural volatile organic compound emissions, J. Geophys. Res., 100, 8873-8892, 1995.

Guenther, A., Karl, T., Harley, P., Wiedinmyer, C., Palmer, P. I., and Geron, C.: Estimates of global terrestrial isoprene emissions using MEGAN (Model of Emissions of Gases and Aerosols from Nature), Atmos. Chem. Phys., 6, 3181-3210, doi:10.5194/acp-63181-2006, 2006.

Hauglustaine, D. A., Hourdin, F., Jourdain, L., Filiberti, M.A., Walters, S., Lamarque, J.-F., and Holland, E.: Interactive chemistry in the Laboratoire de Meteorologie Dynamique general circulation model: Description and background tropospheric chemistry evaluation, J. Geophys. Res., 109, D04314, doi:10.1029/2003JD003957, 2004.

Hak, C., Pundt, I., Trick, S., Kern, C., Platt, U., Dommen, J., Ordóñez, C., Prévôt, A. S. H., Junkermann, W., Astorga-Lloréns, C., Larsen, B. R., Mellqvist, J., Strandberg, A., Yu, Y., Galle, B., Kleffmann, J., Lörzer, J. C., Braathen, G. O., and Volkamer, R.: Intercomparison of four different in-situ techniques for ambient formaldehyde measurements in urban air, Atmos. Chem. Phys., 5, 2881-2900, doi:10.5194/acp-5-2881-2005, 2005.

Heald, C., Jacob, D., Jones, D., Palmer, P., Logan, J., Streets, D., Sachse, G., Gille, J., Hoffman, R., and Nehrkorn, T.: Comparative inverse analysis of satellite (MOPITT) and aircraft (TRACEP) observations to estimates Asian sources of carbon monoxide, J. Geophys. Res., 109, D23306, doi:10.1029/2004GL005185, 2004.

Hourdin, F., Musat, I., Bony, S., Braconnot, P., and Codron, F.: The LMDZ4 general circulation model: climate performance and sensitivity to parametrized physics with emphasis on tropical convection, Clim. Dynam., 27, 787-813, doi:10.1007/s00382006-0158-0, 2006.

IPCC: Climate Change 2007: The Physical Science Basis. Contribution of Working Group I to the Fourth Assessment: Report of the Intergovernmental Panel on Climate Change, edited by: Solomon, S., Qin, D., Manning, M., Chen, Z., Marquis, M., Averyt, K. B., Tignor, M., and Miller, H. L., Cambridge University Press, Cambridge, UK and New York, NY, USA, 996 pp., 2007.

Kopacz, M., Jacob, D. J., Fisher, J. A., Logan, J. A., Zhang, L., Megretskaia, I. A., Yantosca, R. M., Singh, K., Henze, D. K., Burrows, J. P., Buchwitz, M., Khlystova, I., McMillan, W. W., Gille, J. C., Edwards, D. P., Eldering, A., Thouret, V., and Nedelec, P.: Global estimates of CO sources with high resolution by adjoint inversion of multiple satellite datasets (MOPITT, AIRS, SCIAMACHY, TES), Atmos. Chem. Phys., 10, 855-876, doi:10.5194/acp-10-855-2010, 2010.

Krol, M. and Lelieveld, J.: Can the variability in tropospheric $\mathrm{OH}$ be deduced from measurements of 1,1,1-trichloroethane (methyl chloroform)?, J. Geophys. Res., 108, 4125, doi:10.1029/2002JD002423, 2003.

Kuhn, U., Rottenberger, S., Biesenthal, T., Wolf, A., Schebeske, G., Ciccioli, P., Brancaleoni, E., Frattoni, M., Tavares, T.
M., and Kesselmeier, J.: Seasonal differences in isoprene and light-dependent monoterpene emission by Amazonian tree species, Glob. Change Biol., 10, 663-682, doi:10.1111/j.15298817.2003.00771.x, 2004.

Kurosu, T. P.: OMHCHO README FILE, http://www.cfa. harvard.edu/ tkurosu/SatelliteInstruments/OMI/PGEReleases/ READMEs/OMHCHO_README.pdf, 2008.

Lamarque, J.-F., Bond, T. C., Eyring, V., Granier, C., Heil, A., Klimont, Z., Lee, D., Liousse, C., Mieville, A., Owen, B., Schultz, M. G., Shindell, D., Smith, S. J., Stehfest, E., Van Aardenne, J., Cooper, O. R., Kainuma, M., Mahowald, N., McConnell, J. R., Naik, V., Riahi, K., and van Vuuren, D. P.: Historical (1850-2000) gridded anthropogenic and biomass burning emissions of reactive gases and aerosols: methodology and application, Atmos. Chem. Phys., 10, 7017-7039, doi:10.5194/acp10-7017-2010, 2010.

Lathière, J., Hauglustaine, D. A., Friend, A. D., De NobletDucoudré, N., Viovy, N., and Folberth, G. A.: Impact of climate variability and land use changes on global biogenic volatile organic compound emissions, Atmos. Chem. Phys., 6, 2129-2146, doi:10.5194/acp-6-2129-2006, 2006.

Lee, M., Heikes, B. G., and Jacob, D. J.: Enhancements of hydroperoxydes and formaldehyde in biomass burning impacted air and their effect on atmospheric oxidant cycles, J. Geophys. Res., 103, D11, doi:10.1029/98JD00578, 1998.

Levelt, P., Hilsenrath, E., Leppelmeier, G., van den Oord, G., Bhartia, P., Tamminen, J., de Haan, J., and Veefkinf, J.: Science objectives of the Ozone Monitoring Instrument., Geo. Rem. Sens., 44, 1199-1208, 2006.

Lewis, S. M., Brando, P. M., Philipps, O. L., van der Heijden, G. M. F., and Nepstad, D.: The 2010 Amazon drought, Science, 331, 6017, doi:10.1126/science.1200807, 2011.

Logan, J. A., Megretskaia, I., and Nassar, R.: Effects of the 2006 El Niño on tropospheric composition as revealed by data from the Tropospheric Emission Spectrometer (TES), Geophys. Res. Lett., 35, L03816, doi:10.1029/2007GL031698, 2008.

Marais, E. A., Jacob, D. J., Kurosu, T. P., Chance, K., Murphy, J. G., Reeves, C., Mills, G., Casadio, S., Millet, D. B., Barkley, M. P., Paulot, F., and Mao, J.: Isoprene emissions in Africa inferred from OMI observations of formaldehyde columns, Atmos. Chem. Phys. Discuss., 12, 7475-7520, doi:10.5194/acpd12-7475-2012, 2012.

Millet, D. B., Jacob, D. J., Turquety, S., Hudman, R. C., Wu, S., Fried, A., Walega, J., Heikes, B. G., Blake, D. R., Singh, H. B., Anderson, B. E., and Clarke, A. D.: Formaldehyde distributions over North America: Implications for satellite retrievals of formaldehyde columns and isoprene emissions, J. Geophys. Res., 111, D24S02, doi:10.1029/2005JD006853, 2006.

Millet, D. B., Jacob, D. J., Boersma, K. F., Fu, T. M., Kurosu, T. P., Chance, K., Heald, C. L., and Guenther, A.: Spatial distribution of isoprene emissions from North America derived from formaldehyde column measurements by the OMI satellite sensor, J. Geophys. Res., 113, D02307, doi:10.1029/2007JD008950, 2008.

Montzka, S. A., Krol, M., Dlugokencky, E., Hall, B., Jockel, P., and Lelieveld, J.: Small Interannual Variability of Global Atmospheric Hydroxyl, Science, 331, 67-69, doi:10.1126/science.1197640, 2011. 
Müller, J.-F., Stavrakou, T., Wallens, S., De Smedt, I., Van Roozendael, M., Potosnak, M. J., Rinne, J., Munger, B., Goldstein, A., and Guenther, A. B.: Global isoprene emissions estimated using MEGAN, ECMWF analyses and a detailed canopy environment model, Atmos. Chem. Phys., 8, 1329-1341, doi:10.5194/acp-81329-2008, 2008.

NASA: OMHCHO readme file, http://disc.sci.gsfc.nasa.gov/Aura/ data-holdings/OMI/omhcho_v003.shtml, 2008.

Olivier, J. and Berdowski, J.: Global emissions sources and sinks, The Climate System, 33-78, 2001.

Palmer, P., Jacob, D., Jones, D., Heald, C., Yantosca, R., Logan, J., Sachse, G., and Streets, D.: Inverting for emissions of carbon monoxide from Asia using aircraft observations over the Western Pacific, J. Geophys. Res., 108, 8828, doi:10.1029/2003JD003397, 2003.

Palmer, P., Jacob, D., Jones, D., Heald, C., Yantosca, R., Logan, J., Sachse, G., and Streets, D.: Quantifying the seasonal and interannual variability of North American isoprene emissions using satellite observations of formaldehyde columns, J. Geophys. Res., 111, D12315, doi:10.1029/2005JD006689, 2006.

Palmer, P., Barkley, M. P., Kurosu, T. P., Lewis, A. C., Saxton, J. E. Chance, K., and Gatti, L. V.: Interpreting satellite column observations of formaldehyde over tropcial South America, Phil. Trans. R. Soc. A, 365, 1741-1751, doi:10.1098/rsta.2007.2042, 2007.

Pétron, G., Granier, C., Khattatov, B., Yudin, V., Lamarque, J.-F., Emmons, L., Gille, J., and Edwards, D.: Monthly CO surface sources inventory based on the 2000-2001 MOPITT satellite data, Geophys. Res. Lett, 31, L21107, doi:10.1029/2004GL020560, 2004.

Pfister, G., Hess, P., Emmons, L., Lamarque, J.-F., Wiedinmyer, C., Edwards, D., Pétron, G., Gille, J., and Sachse, G.: Quantifying CO emissions from the 2004 Alaskan wildfires using MOPITT CO data, Geophys. Res. Lett, 32, L11809, doi:10.1029/2005GL022995, 2004.

Pison, I., Bousquet, P., Chevallier, F., Szopa, S., and Hauglustaine, D.: Multi-species inversion of $\mathrm{CH}_{4}, \mathrm{CO}$ and $\mathrm{H}_{2}$ emissions from surface measurements, Atmos. Chem. Phys., 9, 5281-5297, doi:10.5194/acp-9-5281-2009, 2009.

Prinn, R. G., Huang, J., Weiss, R. F., Cunnold, D. M., Fraser, P., Simmonds, P. G., McCulloch, A., Harth, C., Salameh, P., ODoherty, S., Wang, R. H. J., Porter, L., and Miller, B. R.: Evidence for substantial variations of atmospheric hydroxyl radicals in the past two decades, Science, 292, 1882-1888, 2001.

Prinn, R. G., Huang, J., Weiss, R. F., Cunnold, D. M., Fraser, P. J., Simmons, P. G., McCulloch, A., Harth, C., Reimann, S., Salameh, P., O’Doherty, S., Wang, R. H. J., Porter, L. W., Miller, B. R., and Krummel, P. B.: Evidence for variability hydroxyl radicals over the past quarter century, Geophys. Res. Lett, 32, L07809, doi:10.1029/2004GL022228, 2005.

Reeves, C. E., Formenti, P., Afif, C., Ancellet, G., Attié, J.-L., Bechara, J., Borbon, A., Cairo, F., Coe, H., Crumeyrolle, S., Fierli, F., Flamant, C., Gomes, L., Hamburger, T., Jambert, C., Law, K. S., Mari, C., Jones, R. L., Matsuki, A., Mead, M. I., Methven, J., Mills, G. P., Minikin, A., Murphy, J. G., Nielsen, J. K., Oram, D. E., Parker, D. J., Richter, A., Schlager, H., Schwarzenboeck, A., and Thouret, V.: Chemical and aerosol characterisation of the troposphere over West Africa during the monsoon period as part of AMMA, Atmos. Chem. Phys., 10,
7575-7601, doi:10.5194/acp-10-7575-2010, 2010.

Sander, S. P., Finalyson-Pitts, B. J., Friedl, R. R., Golden, D. M., Huie, R. E., Keller-Rudeck, H., Kolb, C. E., Kurylo, M. J., Molina, M. J., Moortgat, G. K., Orkin, L. V., Ravishankara, A. R., and Wine, P. H.: Chemical Kinetics and Photochemical data for use in atmospheric studies, Evaluation number 15, NASA Panel for data evaluation, JPM Publication 06-2, Jet Propulsion Laboratory, Pasadena, 2006.

Schroeder, W., Giglio, L., and Aravequia, J. A.: Comment on "Reversal of trend of biomass burning in the Amazon" by Ilan Koren, Lorraine A. Remer, and Karla Longo, Geophys. Res. Lett., 36, L03806, doi:10.1029/2008GL035659, 2009.

Shim, C., Wang, Y., Choi, Y., Palmer, P. I., Abbot, D. S., and Chance, K.: Constraining global isoprene emissions with Global Ozone Monitoring Experiment (GOME) formaldehyde column measurements, J. Geophys. Res., 110, D24301, doi:10.1029/2004JD005629, 2005.

Singh, H. B., Brune, W. H., Crawford, J. H., Flocke, F., and Jacob, D. J.: Chemistry and transport of pollution over the Gulf of Mexico and the Pacific: spring 2006 INTEX-B campaign overview and first results, Atmos. Chem. Phys., 9, 2301-2318, doi:10.5194/acp-9-2301-2009, 2009.

Stavrakou, T. and Müller, J.-F.: Grid-based versus big region approach for inverting $\mathrm{CO}$ emissions using MOPITT data, J. Geophys. Res., 111, D15304, doi:10.1029/2007GL030231, 2006.

Stavrakou, T., Müller, J.-F., De Smedt, I., Van Roozendael, M., van der Werf, G. R., Giglio, L., and Guenther, A.: Global emissions of non-methane hydrocarbons deduced from SCIAMACHY formaldehyde columns through 2003-2006, Atmos. Chem. Phys., 9, 3663-3679, doi:10.5194/acp-9-3663-2009, 2009.

Szopa, S., Hauglustaine, D., and Ciais, P.: Relative contributions of biomass burning emissions and atmospheric transport to carbon monoxide interannual variability, Geophys. Res. Lett., 34, L18810, doi:10.1029/2007GL030231, 2007.

Tanimoto, H., Sawa, Y., Yonemura, S., Yumimoto, K., Matsueda, H., Uno, I., Hayasaka, T., Mukai, H., Tohjima, Y., Tsuboi, K., and Zhang, L.: Diagnosing recent CO emissions and ozone evolution in East Asia using coordinated surface observations, adjoint inverse modeling, and MOPITT satellite data, Atmos. Chem. Phys., 8, 3867-3880, doi:10.5194/acp-8-3867-2008, 2008.

Torres, O., Chen, Z., Jethva, H., Ahn, C., Freitas, S. R., and Bhartia, P. K.: OMI and MODIS observations of the anomalous 20082009 Southern Hemisphere biomass burning seasons, Atmos. Chem. Phys., 10, 3505-3513, doi:10.5194/acp-10-3505-2010, 2010.

Yurganov, L., McMillan, W., Dzhola, A., Grechko, E., Jones, N., and van der Werf, G.: Global AIRS and MOPITT CO Measurements : Validation, Comparison, and Links to Biomass Burning Variations and Carbon Cycle, J. Geophys. Res., 113, D09301, doi:10.1029/2007JD009229, 2008.

Yurganov, L., McMillan, W., Grechko, E., and Dzhola, A.: Analysis of global and regional $\mathrm{CO}$ burdens measured from space between 2000 and 2009 and validated by ground-based solar tracking spectrometers, Atmos. Chem. Phys., 10, 3479-3494, doi:10.5194/acp-10-3479-2010, 2010.

van der Werf, G. R., Randerson, J. T., Giglio, L., Collatz, G. J., Kasibhatla, P. S., and Arellano Jr., A. F.: Interannual variability in global biomass burning emissions from 1997 to 2004, Atmos. Chem. Phys., 6, 3423-3441, doi:10.5194/acp-6-3423-2006, 
2006.

van der Werf, G. R., Randerson, J., Giglio, L., Gobron, N., and Dolman, A. J.: Climate controls on the variability of fires in the tropics and subtropics, Global Biogeochem. Cy., 22, GB3028, doi:10.1029/2007GB003122, 2008.

van der Werf, G. R., Randerson, J. T., Giglio, L., Collatz, G. J., Mu, M., Kasibhatla, P. S., Morton, D. C., DeFries, R. S., Jin, Y., and van Leeuwen, T. T.: Global fire emissions and the contribution of deforestation, savanna, forest, agricultural, and peat fires (19972009), Atmos. Chem. Phys., 10, 11707-11735, doi:10.5194/acp10-11707-2010, 2010
Zimmerman, P. R., Greenberg, J. P., and Westberg, C. E.: Measurements of Atmospheric Hydrocarbons and Biogenic Emission Fluxes in the Amazon Boundary Layer, J. Geophys. Res., 93, 1407-1416, doi:10.1029/JD093iD02p01407, 1988. 